\title{
Role of Monoamine Oxidase Activity in Alzheimer's Disease: An Insight into the Therapeutic Potential of Inhibitors
}

\author{
Tapan Behl ${ }^{1, *}$, Dapinder Kaur ${ }^{1}$, Aayush Sehgal ${ }^{1}$, Sukhbir Singh ${ }^{1}$, Neelam Sharma ${ }^{1}$, Gokhan Zengin ${ }^{2}$, \\ Felicia Liana Andronie-Cioara ${ }^{3}{ }^{1}$, Mirela Marioara Toma ${ }^{4,5}$, Simona Bungau $4,5, * \mathbb{1}$ and Adrian Gheorghe Bumbu ${ }^{6}$
}

Citation: Behl, T.; Kaur, D.; Sehgal, A.; Singh, S.; Sharma, N.; Zengin, G.; Andronie-Cioara, F.L.; Toma, M.M.; Bungau, S.; Bumbu, A.G. Role of Monoamine Oxidase Activity in Alzheimer's Disease: An Insight into the Therapeutic Potential of Inhibitors. Molecules 2021, 26, 3724. https://doi.org/10.3390/ molecules26123724

Academic Editors: Leonardo Pisani and Modesto De Candia

Received: 17 May 2021

Accepted: 16 June 2021

Published: 18 June 2021

Publisher's Note: MDPI stays neutral with regard to jurisdictional claims in published maps and institutional affiliations.

Copyright: (c) 2021 by the authors. Licensee MDPI, Basel, Switzerland. This article is an open access article distributed under the terms and conditions of the Creative Commons Attribution (CC BY) license (https:// creativecommons.org/licenses/by/ $4.0 /)$.
1 Department of Pharmacology, Chitkara College of Pharmacy, Chitkara University, Rajpura 140401, Punjab, India; dapinderk78@gmail.com (D.K.); aayushsehgal00@gmail.com (A.S.); sukhbir.singh@chitkara.edu.in (S.S.); neelam.mdu@gmail.com (N.S.)

2 Department of Biology, Faculty of Science, Selcuk University Campus, 42130 Konya, Turkey; biyologzengin@gmail.com

3 Department of Psycho-Neuroscience and Recovery, Faculty of Medicine and Pharmacy, University of Oradea, 410073 Oradea, Romania; felicia_cioara@yahoo.com

4 Department of Pharmacy, Faculty of Medicine and Pharmacy, University of Oradea, 410028 Oradea, Romania; mire.toma@yahoo.com

5 Doctoral School of Biomedical Sciences, University of Oradea, 410073 Oradea, Romania

6 Department of Surgical Disciplines, Faculty of Medicine and Pharmacy, University of Oradea, 410073 Oradea, Romania; abumbu@uoradea.ro

* Correspondence: tapanbehl31@gmail.com (T.B.); simonabungau@gmail.com (S.B.)

Abstract: Despite not being utilized as considerably as other antidepressants in the therapy of depression, the monoamine oxidase inhibitors (MAOIs) proceed to hold a place in neurodegeneration and to have a somewhat broad spectrum in respect of the treatment of neurological and psychiatric conditions. Preclinical and clinical studies on MAOIs have been developing in recent times, especially on account of rousing discoveries manifesting that these drugs possess neuroprotective activities. The altered brain levels of monoamine neurotransmitters due to monoamine oxidase (MAO) are directly associated with various neuropsychiatric conditions like Alzheimer's disease (AD). Activated $\mathrm{MAO}$ induces the amyloid-beta $(\mathrm{A} \beta)$ deposition via abnormal cleavage of the amyloid precursor protein (APP). Additionally, activated MAO contributes to the generation of neurofibrillary tangles and cognitive impairment due to neuronal loss. No matter the attention of researchers on the participation of MAOIs in neuroprotection has been on monoamine oxidase-B (MAO-B) inhibitors, there is a developing frame of proof indicating that monoamine oxidase-A (MAO-A) inhibitors may also play a role in neuroprotection. The therapeutic potential of MAOIs alongside the complete understanding of the enzyme's physiology may lead to the future advancement of these drugs.

Keywords: Alzheimer's disease; monoamine oxidase; monoamine oxidase inhibitors; monoaminergic neurotransmitters; oxidative stress; neuroinflammation; reactive aldehydes

\section{Introduction}

Amongst the various neurodegenerative disorders, Alzheimer's disease (AD), a progressive form of neuronal cell degeneration, is well known to influence older humans and is estimated to affect 131.5 million people by 2050 [1]. AD is the most habitual root of dementia which is characterized by a substantial cognition loss, including intellectual, language, visual-spatial disturbances as well as memory damage [2]. As the disease advances, neuropsychiatric symptoms increase, and daily performance decreases [3]. Pathologically, $\mathrm{AD}$ is identified through the deposition of intracellular neurofibrillary tangles (NFTs) and extracellular senile plaques possessing amyloid- $\beta(\mathrm{A} \beta)$ proteins, which, alongside neuronal death and cerebral atrophy, constitutes the hallmark attributes of the disorder. The brain of AD patients is also distinguished via the existence of an "inflammatory" cascade, even 
in initial phases. Such cascade catalyzes microglia and astroglia activation, which subsequently stimulates multiple signaling pathways $[4,5]$ to generate inflammatory responses like reactive oxygen species (ROS) and cytokines, resulting in oxidative stress [6].

Hallmarks of oxidative stress are perceived initially in AD, indicating that ROS could engage in the torrent of episodes producing neurodegeneration [7]. Monoamine oxidase (MAO), an enzyme confined to the superficial membrane of mitochondria [8], is crucially involved in the metabolism of monoamine neurotransmitters and other amines as well [9]. MAO catalyzed oxidative deamination generates hydrogen peroxide $\left(\mathrm{H}_{2} \mathrm{O}_{2}\right)$, a negotiator of oxidative stress. MAO exists in two forms (monoamine oxidase-A (MAO-A) and monoamine oxidase-B (MAO-B)), encoded by two different genes, and having distinct tissue allocation systems and separate substrate specificity. MAO-B, the main isoform located in the brain [10], deactivates neurotransmitters such as dopamine, trace amines such as 2-phenylethylamine (PEA), and possibly other neuro-modulatory amines like polyamines [11].

The expression of MAO-B is enhanced in the hippocampus and cerebral cortex of $\mathrm{AD}$ brains in comparison to healthy brains [12] and enhanced degree (more than 3-fold) of active MAO-B are located in reactive astrocytes encircling amyloid- $\beta$ deposits [13]. This overexpression of MAO-B in astrocytes is theorized to catalyze imprudent metabolism of monoamines and enhanced generation of free radicals and hydrogen peroxide $\left(\mathrm{H}_{2} \mathrm{O}_{2}\right)$ and thus may feasibly advance the neurodegenerative mechanisms occurring in $\mathrm{AD}$ [14]. Such a process seems to be a prodromal episode in $\mathrm{AD}$ that continues throughout disease advancement [15].

Considering the presumed character of MAO-B in $\mathrm{AD}$, inhibition of MAO-B expression could be predicted to decrease oxidative stress and neurodegeneration, hence potentially detaining the disease progression. Additionally, MAO-B inhibition can adjust the level of neuro-modulatory amines that might be advantageous for intellectual indications. In fact, an irreversible selective MAO-B inhibitor selegiline was discovered to possess a positive impact on cognitive functions in AD patients [16]. Nevertheless, the therapeutical approach of selegiline in $\mathrm{AD}$ remains contentious due to negligence in clinical trials. In phase 2 of the clinical trial, administration of lazabemide, a potent MAO-B inhibitor, determines a $20-40 \%$ depletion in cognitive decline in comparison to controls [17]. Despite these outcomes were evocative of a treatment impact on symptom advancement, the development of lazabemide was seized due to possible toxicity patterns. Hence, the overall portrayal of the review provides a clearer indication of the neuropharmacological significance of targeting monoaminergic systems in neurodegenerative disorders and the need for future research.

\section{General Physiology of Monoamine Oxidases}

MAO is a mitochondrial-limited enzyme with peak appearance extent in gastrointestinal and neuronal tissues. MAO occurs in two distinct isoforms, namely MAO-A and $\mathrm{MAO}-\mathrm{B}$, which indicates substantial structure resemblance but vary in tissue distribution and their substrate-inhibitor identification regions. They induce the oxidative deamination of multiple monoamines, thus being crucially involved in the metabolization of a range of neurotransmitters. The altered cerebral levels of the neurotransmitters are associated with the pathophysiology of various neurodegenerative diseases such as Parkinson's disease, depression, and Alzheimer's disease [18].

Flavin binding MOA induces the oxidative deamination of monoamine analogs along with neurotransmitters such as adrenaline and noradrenaline, norepinephrine (NE), dopamine, 2-phenylethylamine (PEA), tyramine, exogenous amines like 1-methyl-4-phenyl1,2,3,6-tetrahydropyridine (MPTP) and serotonin (5-HT), producing neurotoxic molecules like $\mathrm{H}_{2} \mathrm{O}_{2}$, aldehydes, and substituted amines or ammonia. MAOs are a class of flavoenzyme oxidases in which the oxidation uses $\mathrm{O}_{2}$ as an electron acceptor molecule to produce hydrogen peroxide under the influence of a catalyst. This catalytic reaction is based on the character of the substrate for both MAO-A and MAO-B isoforms. Both isoforms of MAO share $73 \%$ sequence resemblance, but vary mostly in their substrate-inhibitor specificity, 
and tissue allocation. The substrate selectivity in MAO-A form has large intrinsic amines like epinephrine, serotonin, and norepinephrine, whereas substrate selectivity in MAO-B form has small amines like b-phenylethylamine, benzylamine, and some common amines for both forms include tyramine and dopamine.

Mitochondrial-based MAO is mainly located in the human brain, though MAO-A manifests in the intestines, heart, and placenta whereas MAO-B is restricted to cerebral glial cells, platelets, and hepatic cells. MAOs also controls mood, motor activity and assents brain and motivational activities [19-21]. In peripheral organs like the intestine, lungs, placenta, and liver, MAOs shield the body by systemic oxidation of amines or prevents their ingression into the blood. It has been observed that MAO-B in capillaries of the blood-brain barrier (BBB) executes a preservative action and acts as a metabolic barricade. It was also acknowledged that intracerebral MAO-A and MAO-B protect neurons against exogenous amines, ceasing the function of amine neurotransmitters, and intrinsic amine store declines in cerebral as well as peripheral tissues. The cerebral monoamines like serotonin, dopamine, and norepinephrine are perpetually metabolized, which is essential for neuronal transmission and to regulate some of the emotional activities (as shown in Figure 1).

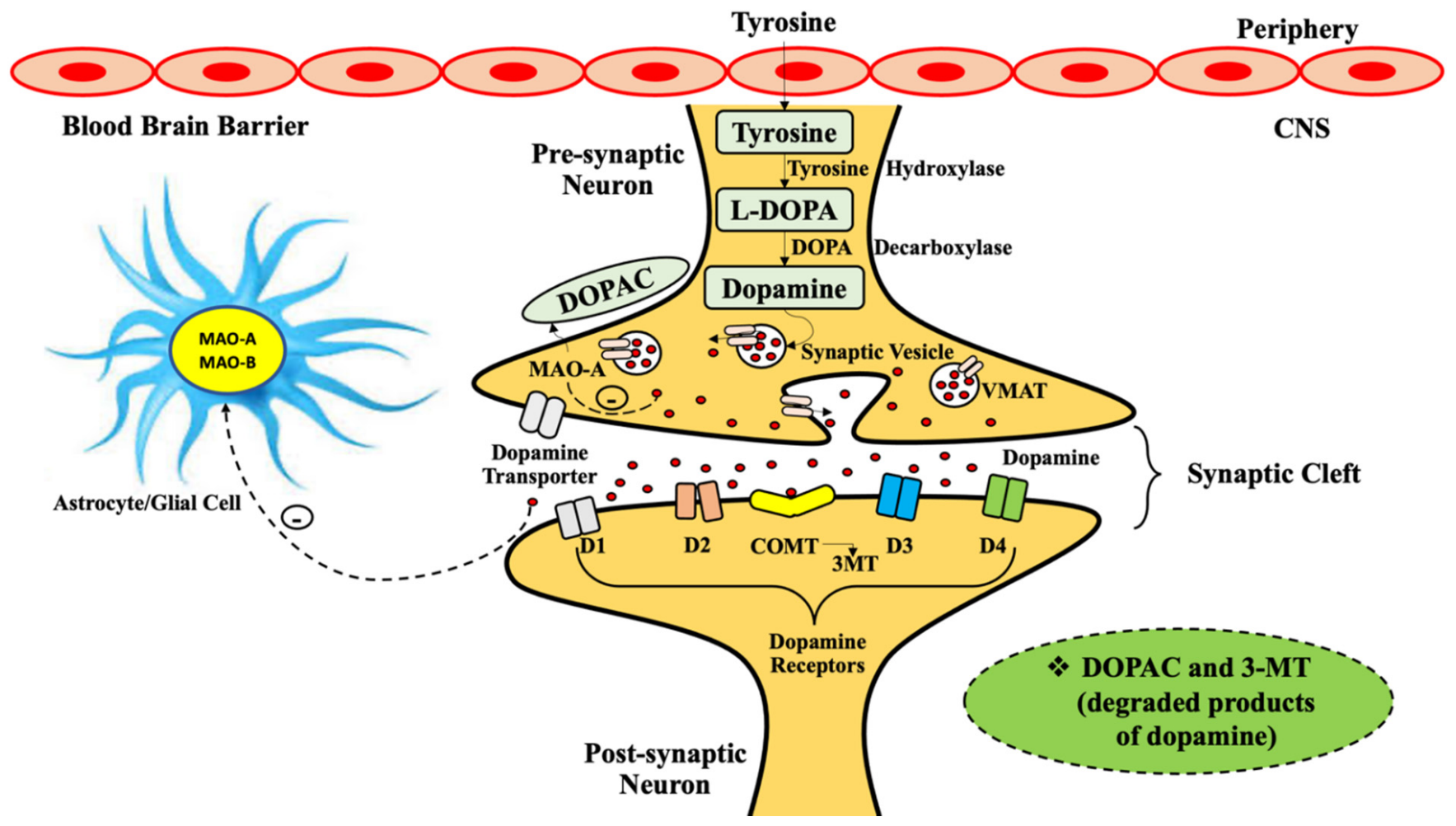

Figure 1. The dopamine synthesis initiates from tyrosine, which crosses the blood-brain barrier (BBB) and transforms into 1-dihydroxyphenylalanine (L-DOPA) via tyrosine hydroxylase (TH). Consecutive decarboxylation by DOPA decarboxylase (DDC) transforms L-DOPA into dopamine neurotransmitter inside neurons. Dopamine is entrapped in synaptic vesicles by VMAT-2 (vesicular monoamine transporter 2) or degraded by monoamine oxidase-A (MAO-A) enzyme present in neurons, and by astrocyte and glial MAO-A and MAO-B enzyme into respective degraded products. Dopamine. D1, D2, D3, D4 are dopamine receptors. Legend: L-DOPA—-1-dihydroxyphenyl alanine; VMAT—vesicular monoamine transporter; COMT-catechol-O-methyltransferase; 3-MT-3-methoxytyramine; DOPAC-3,4-dihydroxyphenyl acetic acid; CNScentral nervous system.

Both isoforms of MAOs, in association with flavin adenine dinucleotide (FAD), induce the oxidative deamination of primary, secondary, and tertiary amines, thus portraying an essential role of FAD in the oxidative deamination of amine substrates. Several neurotransmitters including dopamine, serotonin, and norepinephrine are primary amines that act 
as electron donors to produce imines and give corresponding aldehydes and ammonia on hydrolysis.

The MAO-catalyzed biochemical reaction metabolizes monoamines give respective aldehydes under the activity of aldehyde dehydrogenase (ALDH) enzyme and aldehydes produce acids, alcohols, or glycols by aldehyde reductase (ALR). In these biochemical reactions, various neurotoxic byproducts are produced such as $\mathrm{H}_{2} \mathrm{O}_{2}$ and ammonia $\left(\mathrm{NH}_{3}\right)$. In general, ROS are produced from $\mathrm{H}_{2} \mathrm{O}_{2}$ which is responsible for mitochondrial dysfunction and neuronal death. Generally, this biochemical reaction was further classified into two reactions, half of which is oxidative, and the other half is reductive (as it is shown in Figure 2).

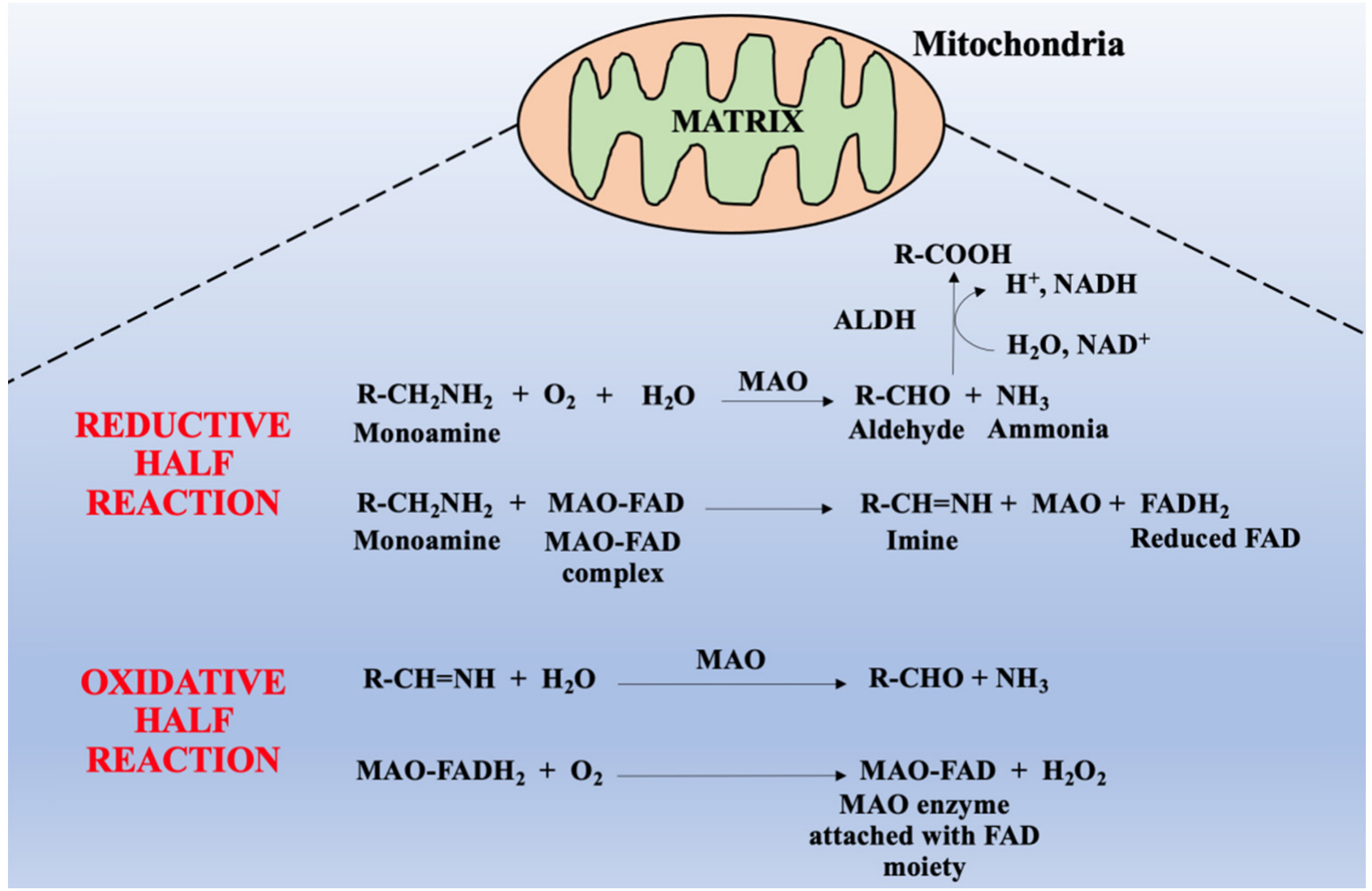

Figure 2. Possible reaction of monoamine-catalyzed generation of reactive species via two successive reactions viz. reductive half-reaction and oxidative half-reaction, leading to oxidative stress. Legend: MAO—monoamine oxidase; FAD—flavin adenine dinucleotide; $\mathrm{FADH}_{2}$ — reduced flavin adenine dinucleotide; MAO-FAD—monoamine oxidase-flavin adenine dinucleotide complex; $\mathrm{H}_{2} \mathrm{O}_{2}$ —hydrogen peroxide; $\mathrm{ALDH}$-aldehyde dehydrogenase; $\mathrm{NADH}$-nicotinamide adenine dinulceotide; $\mathrm{NH}_{3}$-ammonia.

In the reductive reaction, two hydrogen atoms are transferred to the flavin molecule of MAO-FAD complex from amine substrate, thus reducing flavin adenine dinucleotide (FAD) to reduced flavin adenine dinucleotide (FADH2), while in the oxidative reaction, reduced flavin of MAO-FADH2 complex is oxidized to form FAD (MAO-FAD) which produces $\mathrm{H}_{2} \mathrm{O}_{2}$. Whereas amine substrate is oxidized by elimination of two protons and two electrons, the single-bonded C-N amine substrate is transformed into double-bonded imines [22,23]. The comprehensive pathways of amine oxidation are not debated so far, however, researchers have suggested some amine oxidation processes [24]. Lately, three pathways of MAO-catalyzed oxidation were suggested namely, (1) the hydrogen atom transfer (HAT) mechanism, (2) single-electron transfer (SET) or radical transfer mechanism, and (3) the polar nucleophilic pathway [25].

The co-crystal composition of both isoenzymes MAO-A and MAO-B through X-rays with considerable MAOIs has obtained novel understanding into the organization of these enzyme-ligand systems, moreover, it also stimulated the research in the field of MAO 
blockade as a possible therapeutic regime in neurodegenerative disorders [26]. While electron paramagnetic resonance (EPR) investigations manifested that both isoenzymes are structurally dimeric [27], the crystallographic examinations disclosed that the mammalian MAO-A isoform crystallizes as a monomer [28], though MAO-B crystallizes as a dimer. Moreover, the active site of MAO-A comprises one hydrophobic pocket, whereas the bilateral pocket of MAO-B isoform consists of an entrance hydrophobic site and a substratebinding site with the FAD cofactor and entrance hydrophobic cavity [29].

\section{Involvement of Monoamine Oxidase in Alzheimer's Disease}

Since the last five decades, MAOIs were clinically utilized as antidepressants. Currently, a multitude of these MAOIs are active in the treatment of neurodegenerative disorders like Parkinson's disease (PD) and Alzheimer's disease (AD) [18]. In eukaryotes, $\mathrm{MAO}$ is widely distributed in the exterior layer of mitochondria. Altered levels of MAO-A and MAO-B isoenzymes are associated with the degeneration of neurotransmitter biogenic amines such as serotonin, noradrenaline, and dopamine being suggested that they are in relation with multiple conditions such as schizophrenia, depression, antisocial aggressive behaviors, cancer, and neuropsychiatric disorders (NDs) namely PD and AD [30].

It was indicated that few symptoms of $\mathrm{AD}$ are derived from the variation in dopaminergic, serotoninergic, and monoaminergic neurotransmitter signaling associated with both MAO-A and MAO-B isoforms [31]. The MAO-catalyzed oxidative deamination of amine substrates liberates respective byproducts like ammonia, aldehydes, and hydrogen peroxide may be thus engaged in the advancement of $\mathrm{AD}$. In the brain, the MAO-A isoenzyme largely occurs in catecholaminergic neuronal cells, while the isoform MAO-B is largely located in glia and serotonergic neurons.

In post-mortem brain biochemical investigations showed that the variations in MAO$\mathrm{A}$ and $\mathrm{B}$ in the cortex arise in early phases of $\mathrm{AD}$ and remain sustained throughout the development of $\mathrm{AD} \mathrm{[32].} \mathrm{It} \mathrm{has} \mathrm{also} \mathrm{been} \mathrm{noticed} \mathrm{that} \mathrm{the} \mathrm{proportion} \mathrm{of} \mathrm{MAOs} \mathrm{or} \mathrm{mRNA} \mathrm{is}$ elevated in several cerebral regions such as the parietal, frontal, occipital, and temporal cortex and also in the frontal lobe of the neocortex [12]. This indicates that the mechanism in MAO activity could be transcriptional or post-transcriptional and may be responsible for increasing protein synthesis and is also involved in the progression of $\mathrm{AD}$. As the occurrence of reactive $\mathrm{MAO}-\mathrm{B}$ in $\mathrm{AD}$ brains has been noticed it designates the distinct appearance of MAO-A in several regions of the brains of AD cases. Immunostaining studies revealed that the activity of MAO-B isoform was substantially inclined in the cortical and hippocampal regions of AD brains, demonstrating the primary neuronal loss and significant gliosis in such regions of the brain, whereas MAO-A was raised in the hypothalamus and frontal lobe.

In patients of $\mathrm{AD}$, the $\mathrm{MAO}-\mathrm{A}$ expressions seem to be declined in the locus ceruleus, determining $80 \%$ neuronal depletion, proposing that reactive MAO-A in neuronal cells are allied in the pathophysiology of $\mathrm{AD}$ as a susceptible risk factor [33]. Additionally, inclined $\mathrm{MAO}-\mathrm{A}$ expression in AD brains appeared more remarkable in glia and the variation in levels of MAO-A expression in AD might play multiple processes [34]. Stimulation of MAO causes cognitive decline in patients with $\mathrm{AD}$. It has been demonstrated that biomolecular monoamine neurotransmitter systems play a substantial character in cognition mainly awareness, paranoid thinking, memory, attitude, and also emotion and behavior [35].

Some neurotransmitters (for example: cholinesterase, serotoninergic, glutamatergic, noradrenaline) are distressed by $\mathrm{MAO}$, following cognitive dysfunction. Substantial investigation revealed that MAO-A isoform preferentially controls serotonin and noradrenaline and MAO-B acts positively on benzylamine and 2- phenylethylamine [36]. Noradrenaline plays a crucial role in major activities, ruling intellect, cognition, and motivation that are necessary for social interaction. Activation of $\mathrm{MAO}$ is a harmful factor for noradrenaline signaling, impact symptoms of disarranged major activities. Activation of MAO also has a deleterious influence on cholinergic transmission associated with memory and emotion $[37,38]$. 
Presently, scientists showed notable interconnection between MAO-A and catechol-Omethyltransferase-genotypes, such that accessibility of increased prefrontal catecholamine was associated with ameliorated memory functioning. Although, it is not detailed that there is a direct interrelationship between the $\mathrm{MAO}$ and neurotransmitters in AD. Some researchers disclosed that activation of MAO has an indirect connection with several neurotransmitters and cognitive decline in AD.

In $\mathrm{AD}$, the correlation between $\mathrm{MAO}$ activation and oxidative stress is a well-acknowledged source of neurotransmitters impairment, namely, the adrenergic and cholinergic system, which plays a critical role in cognition loss [39]. Additionally, neuroinflammation has a censorious role in cognitive impairment and medium for oxidative stress, while in $\mathrm{AD}, \mathrm{MAO}$ may act as a proinflammatory cytokine, determining cognitive decline (as it is summarized in Figure 3). Reactive MAO enhances cerebral levels of monoamine and modulates other neurotransmitters, resulting in cogitative loss [40].

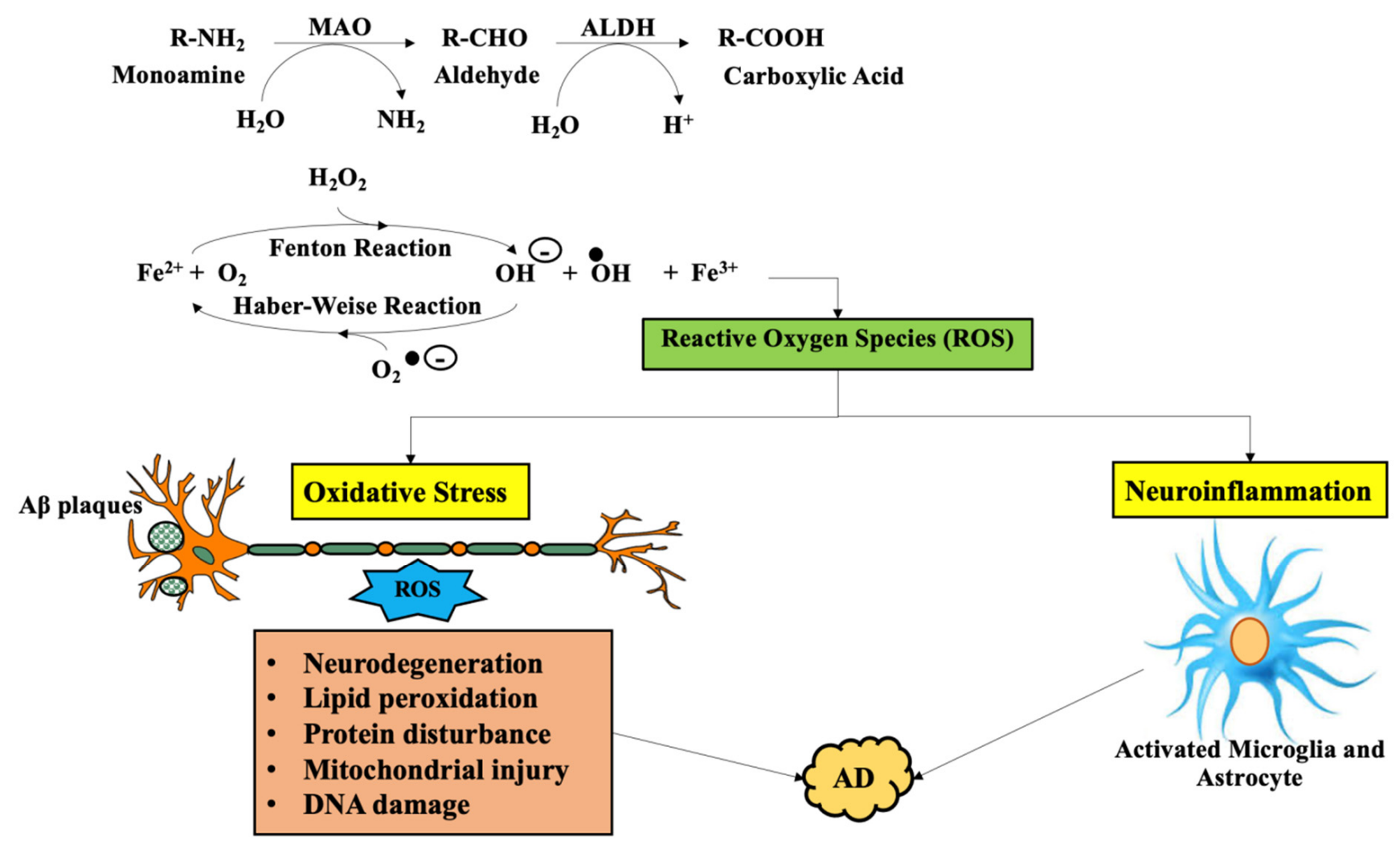

Figure 3. The reactive oxygen species generated by overactive monoamine oxidase in conjunction with Fenton's and Haber-Weise reaction which successively causes neuroinflammation and oxidative stress; implicated in Alzheimer's disease (AD). Legend: $\mathrm{MAO} —$ monoamine oxidase; $\mathrm{ALDH}$ —aldehyde dehydrogenase; $\mathrm{NAD}^{+}$—nicotinamide adenine dinucleotide; $\mathrm{NADH}$ - reduced nicotinamide adenine dinucleotide; $\mathrm{H}_{2} \mathrm{O}_{2}$ - hydrogen peroxide; $\mathrm{O}_{2}$ - singlet oxygen; ROS-reactive oxygen species; $\mathrm{Fe}^{2+}$-ferric ion; $\mathrm{AD}-$ Alzheimer's disease.

In addition, alterations in MAO-linked acid metabolites of serotonin and dopamine (i.e., 5-hydroxyindole-3-acetic acid (5- HIAA) and homovanillic acid (HVA), respectively) are associated with cognitive dysfunction and dementia, as experimentally noticed in several animal models of AD. At first, greater activity of MAO was noticed in brains and platelets of AD cases, though in CNS, activity of MAO-B advances with age as MAO-B level increases. As compared with gender and age, MAO activity was remarkably uplifted in platelets of AD patients, and the MAO-B activity but not MAO-A activity was significantly larger in hippocampus and cortex of the gyrus cinguli of AD patients. Evidence indicated the direct relationship between symptoms, MAO-B activity in platelets and the cerebrospinal fluid (CSF) monoamine metabolites revealed the significance of 
MAO-B expression in the platelets as the pathological marker of AD. Therefore, enhanced MAO-B expression may account as an indicator for vulnerability towards AD. As per Mini-Mental State Examination (MMSE) of three groups with 23 patients in the early phase, 23 patients in the middle phase, and in 28 patients in the last phase of $\mathrm{AD}$, also matched with 49 elderly controls, the substantial connection between age and MMSE scores and MAO-B activity were recognized, manifesting that such indicators may portray the complexity and therapeutic progression of $\mathrm{AD}$ [41]. Activation of MAO-B also contributes to the production of amyloid- $\beta$ plaques. Observations on the pathophysiological framework of $\mathrm{AD}$ have signified that there is an oxidative injury in $\mathrm{AD}$. Oxidative tension in patients of AD catalyzes amyloid- $\beta$ plaque generation. Enhanced MAO-B activity in hippocampus and cerebral cortex of $\mathrm{AD}$ regulates healthy $\mathrm{CNS}$ and active MAO-B inclined measure located in sensitive astrocytes all around amyloid- $\beta$ plaques. In astrocytes, enhanced level of MAO-B, is considered an indicator of oxidative tension, in the imprudent oxidative deamination of monoamines which produces more hydrogen peroxide and free radicals, consequently advances $\mathrm{AD}$ progression, such process appears to be an initial stage in the advancement of $\mathrm{AD}[15]$.

In $\mathrm{AD}$, Figure 4 describes how the monoamine activity may impact the clinical features of a neurodegenerative disorder such as by cleavage of amyloid precursor protein (APP). The molecular biology studies of $A \beta$ production proposed that it results from two consecutive cleavages of APP via two distinct enzymes, namely, $B$-secretase (b-site APP cleavage enzyme or BACE) and $\Gamma$-secretase following MAO activation [42]. The initial step involves the extracellular $\beta$-secretase cleavage to produce A $\beta$ between APP residues of Met671 and Asp67, generating an insoluble cell membrane-bound segment and an extracellular segment. The cell membrane-bound segment is further cleaved by $\Gamma$-secretase in the lipophilic transmembrane domain, subsequently generating $A \beta$ an intracellular fragment of APP. APP generates toxic A $\beta$ fibrils in AD brains under the influence of serotonin via activation of various serotoninergic receptors [43]. Furthermore, acid monoamine metabolites are associated with the cerebrospinal levels of $A \beta$, while enhanced MAO-B expression in plaques linked with astrocytes is a clinical feature of $\mathrm{AD}$ advancement [41].

This correlation was currently reassured in imaging 5xFAD using two-photon in the AD model [44]. Lately, MAO-B has progressed as a potential therapeutic target for AD. MAO-B is rigidly associated with the production of $\Gamma$-aminobutyric acid (GABA) in susceptible astrocytes, consequently memory loss in an animal model of $A D$, due to the inhibition of synaptic transmission and declined spike probability by astrocytic GABA, catalyzing impairment of synaptic plasticity.

Reactive astrocyte-linked generation of GABA is decreased by inhibiting MAO-B, utilizing irreversible MAO-B inhibitors like selegiline (l-deprenyl). Selegiline entirely reinstates cognitive function, impaired spike probability, and synaptic plasticity in $\mathrm{AD}$ models, even in the sight of $A \beta$ peptides. This observation was instituted in the treatment of dementia-type AD. Some biomedical published data also detailed that in patients with AD, selegiline recuperates short-term cognition loss, though, long-term treatment is distressing.

The relationship between oxidative tension and neuroinflammation is a critical feature for the $A \beta$ generation. Additionally, both these factors are crucial in the pathological mechanism of neurodegeneration in $\mathrm{AD}$, signifying that the therapeutic approaches targeting the above 2 processes may be advantageous. It has been described that several MAOIs decrease the $A \beta$ generation by hampering neuroinflammation through inhibiting nuclear factor-kB expression, downregulating the expression of tumor necrosis factor- $\alpha$ and interleukin- $1 \beta$, diminution of glial stimulation [45]. Therefore, proposals for the progression of designing MAOIs as a ligand drug plays a crucial role in AD treatment.

Pre-clinical and clinical evidence, suggesting MAO association with progression of Alzheimer's disease, are presented in Table 1. 


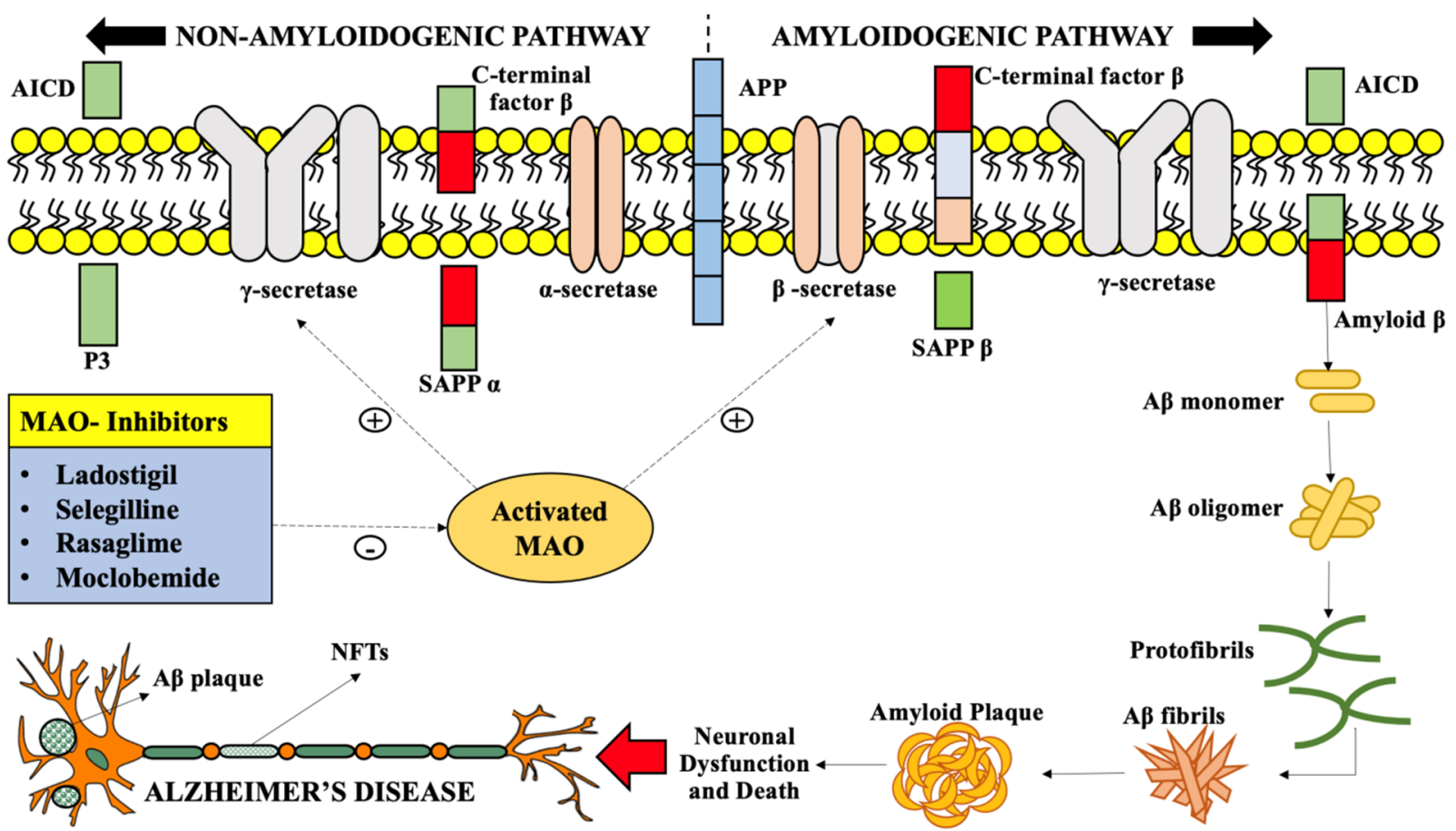

Figure 4. Overactive monoamine oxidase catalyzes the amyloidogenic and non-amyloidogenic cleavage of amyloid precursor protein by directly activating the beta-secretase and gamma-secretase activity, thus leading to aberrant amyloid plaque generation, a hallmark of Alzheimer's disease. Legend: MAO—monoamine oxidase; NFTs—neurofibrillary tangles; $\mathrm{A} \beta$ - amyloid beta; APP—amyloid precursor protein; AICD—amyloid precursor protein intracellular domain; $\mathrm{P}_{3}$-amyloid peptide; SAPP $\alpha$-soluble amyloid precursor protein alpha; $C$-terminal factor $\beta$-carboxy terminal factor beta; $\Gamma$-secretasegamma secretase; $\alpha$-secretase-alpha secretase; $\beta$ - secretase-beta secretase.

Table 1. Pre-clinical and clinical evidence suggesting monoamine oxidase association with progression of Alzheimer's disease.

\begin{tabular}{|c|c|c|c|c|c|}
\hline $\begin{array}{c}\text { Experimental } \\
\text { Model }\end{array}$ & Controls & $\begin{array}{l}\text { Stimulus/Drugs } \\
\text { Employed }\end{array}$ & $\begin{array}{c}\text { Method of } \\
\text { Determination }\end{array}$ & Result/Conclusion & Ref. \\
\hline $\begin{array}{l}11 \text { autopsied } \\
\text { brains of AD } \\
\text { individuals }\end{array}$ & $\begin{array}{l}5 \text { non-AD } \\
\text { individuals }\end{array}$ & $\begin{array}{c}\text { Lazabemide } \\
\text { (MAO-B inhibitor) } \\
\text { Ro41-1049 } \\
\text { (MAO-A inhibitor) }\end{array}$ & Enzyme radiography & $\begin{array}{l}\text { The concentration of MAO } \\
\text { enzyme in the parietal } \\
\text { cortex of AD was } \\
\text { substantially higher as } \\
\text { compared to controls. }\end{array}$ & [46] \\
\hline $\begin{array}{l}3 \text { autopsied brains } \\
\text { of AD patients }\end{array}$ & $\begin{array}{l}3 \text { autopsied brains } \\
\text { of controls }\end{array}$ & L-deprenyl & $\begin{array}{l}\text { Cryo-microtomy } \\
\text { (autoradiography) }\end{array}$ & $\begin{array}{c}\text { The AD patients had } \\
\text { higher MAO-B expression } \\
\text { than the controls }\end{array}$ & [47] \\
\hline $\begin{array}{l}\text { Plaque-associated } \\
\text { astrocytes of brains } \\
\text { of AD patients }\end{array}$ & Literature data & $\begin{array}{l}\text { L-deprenyl, } \\
\text { Pargyline, } \\
\text { Iproniazid }\end{array}$ & Enzymatic assay & $\begin{array}{c}\text { Increased MAO } \\
\text { expression in brains of AD } \\
\text { pIC }_{50} \text { value was } \\
\text { determined of all drugs }\end{array}$ & {$[48]$} \\
\hline $\begin{array}{l}\text { Postmortem brains } \\
\text { of } \mathrm{AD}\end{array}$ & $\begin{array}{l}\text { Autopsied brains } \\
\text { of non-AD } \\
\text { individuals }\end{array}$ & $\begin{array}{l}\text { Gene silencing } \\
\text { (sense and } \\
\text { anti-sense siRNA) }\end{array}$ & $\begin{array}{l}\text { PLA (in situ proximity } \\
\text { ligation assay) } \\
\text { Immunocytochemistry. }\end{array}$ & $\begin{array}{l}\text { Immunocytochemistry } \\
\text { revealed MAO-B staining } \\
\text { in the frontal cortex, } \\
\text { hippocampus, and } \\
\text { entorhinal cortex whose } \\
\text { intensity is higher in AD } \\
\text { brains than in controls. }\end{array}$ & [49] \\
\hline
\end{tabular}


Table 1. Cont.

\begin{tabular}{|c|c|c|c|c|c|}
\hline $\begin{array}{c}\text { Experimental } \\
\text { Model }\end{array}$ & Controls & $\begin{array}{l}\text { Stimulus/Drugs } \\
\text { Employed }\end{array}$ & $\begin{array}{c}\text { Method of } \\
\text { Determination }\end{array}$ & Result/Conclusion & Ref. \\
\hline $\begin{array}{l}60 \text { autopsied } \\
\text { brains of AD } \\
\text { patients }\end{array}$ & $\begin{array}{c}60 \text { autopsied } \\
\text { brains of controls }\end{array}$ & Apo-E4 status & $\begin{array}{c}\text { HPLC } \\
\text { (high-performance } \\
\text { liquid } \\
\text { chromatography) and } \\
\text { immunodetection } \\
\text { (SDS-PAGE) }\end{array}$ & $\begin{array}{l}\text { Increased MAO-A activity } \\
\text { in AD brains has been } \\
\text { associated with prodromal } \\
\text { and co-morbid } \\
\text { neuropsychiatric } \\
\text { symptoms and with } \\
\text { neurodegeneration }\end{array}$ & [50] \\
\hline APP/PS1 mice & $\begin{array}{l}\text { Control mice (wild } \\
\text { type) }\end{array}$ & $\begin{array}{c}\text { Selegiline } \\
\text { (10 mg/kg per day } \\
\text { for } 4 \text { weeks })\end{array}$ & Morris water maze test & $\begin{array}{c}\text { The aberrant GABA level } \\
\text { in APP / PS1 mice was } \\
\text { significantly decreased to } \\
\text { the levels of GABA } \\
\text { observed in wild type } \\
\text { control mice following } \\
\text { selegiline treatment }\end{array}$ & [51] \\
\hline $\begin{array}{l}\text { Adult male Wistar } \\
\text { rats with } \mathrm{AD}\end{array}$ & $\begin{array}{l}\text { Male Wistar rats as } \\
\text { controls }\end{array}$ & $\begin{array}{l}\text { Sembragiline } \\
\qquad(0.3 \%)\end{array}$ & $\begin{array}{l}\text { HPLC + ion-spray } \\
\text { tandem mass } \\
\text { spectrometry }\end{array}$ & $\begin{array}{c}\text { Administration of } \\
\text { sembragiline resulted in } \\
\text { substantially decreased } \\
\text { levels of ROS and } \\
\text { prevented reduced } \\
\text { dopaminergic neuron } \\
\text { numbers in substantia } \\
\text { nigra, when compared } \\
\text { with vehicle-treated mice }\end{array}$ & [52] \\
\hline $\begin{array}{c}\text { Mouse model of } \\
\text { AD }\end{array}$ & Control mice & $\begin{array}{c}\text { 2-photon MAO } \\
\text { probe }\end{array}$ & $\begin{array}{l}\text { Fluorescence TPM } \\
\text { imaging }\end{array}$ & $\begin{array}{c}\text { In vivo correlation } \\
\text { between MAO and } \\
\text { progression of } \\
\text { AD-indicating MAO as a } \\
\text { potential biomarker } \\
\text { of AD. }\end{array}$ & [44] \\
\hline
\end{tabular}

\section{Inhibition of MAO-A and MAO-B as a Therapeutic Approach in Alzheimer's Disease Treatment}

MAOIs raise the monoamine neurotransmitter levels in CNS, namely, dopamine, noradrenaline, and serotonin which were suggested to be practically inadequate in dementia [53]. The MAO-catalyzed reaction induces the generation of reactive aldehydes, $\mathrm{H}_{2} \mathrm{O}_{2}$, and an alkyl-substituted amine or ammonia. Corresponding byproducts are possibly neurotoxic [54], and their generation is hindered by MAOIs. The catalytic oxidation of serotonin and catecholamines by MAO induces the production of 3,4-dihydroxyphenylglycolaldehyde (DOPEGAL) from adrenaline and noradrenaline, 3,4-dihydroxyphenylacetaldehyde (DOPAL) from dopamine, and 5-hydroxyindoleacetaldehyde (5-HIAL) from 5-HT or serotonin. These three metabolites have been proposed to induce neurotoxicity in several pre-clinical and clinical studies [55], thus being involved in the pathophysiology of AD.

The pathophysiological characteristics of MAOs make a possible progression of MAOIs with therapeutic utilization in the treatment of various disorders like neurodegenerative diseases. MAOIs reduce the repercussions of reactive MAO-B, though they have not been considerably employed as therapeutic approaches in AD treatment; similar researches have been carried out mostly with irreversible MAO-B inhibitors like rasagiline and selegiline, and the outcomes in long-standing researches have been unsatisfied in general [56]. Researchers suggested that the GABA/MAO-B interactivity may account for the improvement in cognitive deficits in $\mathrm{AD}$ upon short-term administration of irreversible MAO-B-selective inhibitor, selegiline.

Studies on the amyloid precursor protein/presenilin 1 (APP/PS1) model of AD, found that long-term administration of selegiline attenuates the abnormal GABA measure, firstly 
by inhibiting MAO-B, that ultimately upregulates the expression of the compensating GABA-producing enzyme "diamine oxidase". On the other hand, it was observed that highly selective, reversible MAO-B inhibitors do not show this action and alter cognitive impairment in the $\mathrm{AD}$ mouse model. Because of their actions on reactive aldehydes, singlet oxygen species, and primary amine oxidase (PrAO), MAOIs might be functional adjuvant drugs in the treatment of $\mathrm{AD}$, as their GABA-elevating actions may improve memory and learning abilities. All MAO-related enzymes are of potential interest as a therapeutic target in $\mathrm{AD}$ due to their high-level expression and potential selectivity. Therefore, selective MAO inhibitors were improved to regulate the MAOs expression. The extensive collection of both selective or nonselective reversible and irreversible MAO inhibitors is now available [57]. MAOIs have been mostly implemented in the treatment of neurodegenerative diseases like AD.

The combined overview of molecular biology and pharmacology manifests that MAOIs have neuroprotective functions in the treatment of AD. The considerable neuroprotective actions in AD by MAOIs involves: (a) advancement of iron-chelating and anti-oxidant activity thus preventing hyperphosphorylation of tau protein and oxidative stress, respectively, (b) improvement in cognition, and (c) regulation of A $\beta$ and APP gene expression [58,59]. The evolution of multitarget inhibitors with principal MAO inhibiting activity, combined with iron-chelating activity could be successful therapeutic targets in the treatment of neurodegenerative disorders like AD [60].

The reason why these inhibitors are CNS specific has not been explicated so far. As mentioned above, it is crucial to produce potent specific MAO inhibitors. Thus, immoderate attentiveness should be concentrated on drug design approaches for the development of potent MAO inhibitors. The following are the three main mechanisms of action of MAOIs, implicated in AD.

\subsection{Sequestration of Reactive Aldehydes}

A salient feature that is of substantial attention in respect of potential neuroprotective functions of MAOIs is their resistance to "aldehyde overload", that is, an imprudent measure of reactive aldehydes [61]. Reactive aldehydes may cross-link, and form adducts through the formation of a Schiff base, with nucleic acids, proteins, and amino phospholipids, catalyzing several toxic effects. This may have consequences on hindrance in protein, DNA, and RNA synthesis, disturbed calcium equilibrium, disrupted cell membrane permeability, and alteration of pathways regulating cellular respiration [62]. There has been a considerable understanding of the investigation in the past 20 years targeting the entanglement of reactive aldehydes with neurodegeneration [63,64]. Possible origins of these aldehydes involve carbohydrate autoxidation, lipid peroxidation due to oxidative tension, cytochrome P450-induced oxidation of alcohols, myeloperoxidase-induced oxidative deamination of amino acids, and catalytic expression of amine oxidases [65].

Aldehyde overload and produced toxicity take place due to decreased metabolism of enzymes like aldehyde dehydrogenase, glutathione-S-transferase, and aldo-keto-reductase. Deposition of toxic aldehydes also induces reduction of cellular thiols that sequester the aldehydes, especially the vital antioxidants such as cysteine and glutathione [66]. Clinically, this depletion in intracellular thiols has been observed in AD-related dementia [67]. There have been reports of an increased degree of acrolein and malondialdehyde in the serum, plasma, RBCs, and brains of AD individuals $[68,69]$. Amounts of 4-hydroxy-2-nonenal (4-HNE) have been reported to be elevated in cerebrospinal fluid (CSF) and brains of AD patients, and this toxic aldehyde has been found in the amyloid plaques and neurofibrillary tangles of AD.

Raising levels of toxic aldehydes such as 4-HNE and acrolein have also been observed in the brains of patients with early symptoms of $\mathrm{AD} \mathrm{[70],} \mathrm{proposing} \mathrm{that} \mathrm{an} \mathrm{early} \mathrm{event} \mathrm{in}$ the progression of $\mathrm{AD}$ could be deposition of reactive aldehydes. Long-term administration of acrolein to rats has been described to cause mild cognitive impairment together with neuroinflammation and neuronal loss in the hippocampus; some scientists also reported 
elevated cortical levels of $\beta$-secretase (BACE-1) and demotion in levels of $\alpha$-secretase in the cortex and hippocampus [71,72].

Additionally, it was observed that long-term exposure to acrolein in mouse models causes learning and memory deficits and that there was a positive association between that deterioration and the CSF concentration of acrolein. Hyperphosphorylation of tau protein and induction of tau agglomeration into fibrils have been observed to be catalyzed by acrolein and methylglyoxal [73].

In later stages of $\mathrm{AD}$ (i.e., during advanced oxidative stress) an enhanced amount of acrolein, malondialdehyde, and 4-HNE are distinct [74]. MAOIs such as mercaptoand hydroxylamine compounds are well known to "finish off" or sequester toxic reactive aldehydes via a chemical reaction, but some of these drugs are toxic by themselves. Compounds like hydrazine with an unsubstituted $\mathrm{NH}_{2}$ moiety also react with toxic aldehydes to form innocuous hydrazones. Phenelzine is one such hydrazine, thus being awaited to be utilized to lower the levels and toxicity of reactive aldehydes. In other research, it was located that phenelzine weakens the depletion in the viability of cultured cortical neurons of mouse models generated by acrolein [75] and mop up various in vitro toxic aldehydes, namely, acrolein, formaldehyde, 4-HNE, and malondialdehyde.

Song et al. performed exhaustive research on the actions of phenelzine on formaldehydemediated damage to in vitro primary cortical neuronal cells and astrocytes. Formaldehyde obstructed glutamate take-up by reducing glutamate transporters expression in astrocytes and stimulated the secondary messenger p38 mitogen-activated protein kinase (p38 MAPK), which takes part in a pathway regulating cellular reactions to stress and cytokines, and these actions were reduced by phenelzine [75]. Phenelzine has also been observed to reduce 4-HNE-mediated mitochondrial damage in an animal model [76] of traumatic brain injury [77] and to alleviate 4-HNE-mediated injury to lipids and proteins in blood [78].

\subsection{Incline in $G A B A$ Levels}

Despite the fact that it was used as an MAOI, it is thoroughly reported that phenelzine also induces an increase in CNS levels of GABA in animal models. In 1969 Popov and Matthies observed that the exposure of MAOIs in rats before administering phenelzine, reduced the capability of phenelzine to raise GABA levels in the brain, proposing that a metabolite produced by the action of MAO on phenelzine accounts for the perceived actions. As B-phenyl ethylidene hydrazine (PEH) had been observed as a metabolite of phenelzine, it was indicated that PEH induced a rapid, distinct, and comparatively persistent advancement of brain GABA levels following a single intraperitoneal (i.e.) injection to mouse [79].

Although PEH is a weak MAO inhibitor [80], it inhibits the GABA transaminase (GABA-T) enzyme [81], probably supporting the GABA-raising function of phenelzine. The attentiveness in potential neuroprotective effects of MAOIs was evoked by records implying that several GABAergic agents reduced neurodegeneration in ischemic stroke models [82] and suggesting that such drugs were effective by preventing the detrimental neurotoxic actions of the enhanced glutamate release occurring in ischemic stroke [83].

In fact, there is now colossal literature designating the significance of continuing the neuronal equilibrium between glutamate and GABA and proposing that a disturbance in that equilibrium is a characteristic of various neurological and psychiatric disorders, such as epilepsy, multiple sclerosis, mania, schizophrenia, and depression [84-88]. The scrutinization of MAOIs was presented in an ischemic model in the gerbil (an animal model) that located noticeable neuroprotective actions with such doses of these drugs which causes an elevation in levels of GABA in the brain [89,90].

\subsection{Inhibition of Primary Amine Oxidase}

Primary amine oxidase (PrAO) is a copper-linked laminal glycoprotein, and the extracellular part may be split off, forming an ambient configuration in blood plasma. In some organelles, the laminate configuration is similar to Vascular Adhesion Protein (VAP- 
1) engaged in translocation of white blood cells (WBCs) at inflammatory sites [91,92]. The reactive aldehydes are produced by oxidative deamination of monoamines, through the ambient plasma configuration and the lamina-linked configuration of PrAO. Such aldehydes have manifested to enhance the generation of amyloid- $\beta(A \beta), \beta$-sheets and protofibrils [93], the pair of which are suggested to be a considerable risk to the pathophysiology of AD. Enhanced serum PrAO expression has been observed in patients with AD [94-96] being described a robust activity of PrAO colocalized with A $\beta$ plaques on neurons of autopsied brain samples from AD individuals. Raised PrAO plasma expression has also been observed in multiple sclerosis, diabetes patients, and PrAO inhibition has been beneficially described in the experimental autoimmune encephalomyelitis (EAE) model of multiple sclerosis [97] showing anti-inflammatory effects that are advantageous to vascular health [98]. Ischemia-reperfusion damage in an animal model of stroke is reduced in PrAO-deficit mice and through PrAO inhibitors.

In addition, PrAO inhibition has been observed to contribute to anti-inflammatory protection in a mouse model of intracerebral hemorrhagic stroke $[99,100]$ describing that a PrAO inhibitor had anti-inflammatory and analgesic actions in the chronic arthritis model. It is a concern that MAOIs like phenelzine have also manifested to be a potent PrAO inhibitor; also, it has been indicated that $\mathrm{PEH}$ is a strong in vitro inhibitor of PrAO in clinical studies and that intraperitoneal (i.p.) injection of MAOIs enhances brain levels of methylamine, a secondary measure of depletion of reactive aldehyde levels. These studies and the observations related to the aforementioned actions of MAOIs indicate that research on the actions of MAOIs on AD models is justified.

\subsection{Miscellaneous Neuroprotective Actions of Monoamine Oxidase Inhibitors}

The reactive nitrogen species (RNS), peroxy-nitrite is formed after the reaction between nitric oxide and superoxide anion. Peroxy-nitrite is believed to cause toxic actions following its decomposition producing a hydroxyl radical, nitrogen dioxide radical, and a nitryl cation, all of which may result in marked neurodegeneration in AD [101,102]. Peroxynitrite has been related to a variety of disorders like hypertension, diabetes and may precipitate aging [103]. Studies outlined that MAOIs are preserved from protein nitration, protein carbonyl production, and lipid peroxidation in peroxy-nitrite-exposed platelets and plasma samples. The researchers deduced that the potential of MAOIs to scavenge toxic aldehydes was in charge of its neuroprotective functions in all three of these oxidative stress conditions.

Effects of MAOIs on the brain-derived neurotrophic factor (BDNF) could also be responsible for the neuroprotective actions of these drugs. Chronic exposure of various antidepressants together with MAOIs has been observed to catalyze an incline in central BDNF levels of an AD model [104]. In an experimental study, it was discovered that long-term administration of MAOIs results in enhanced mRNA expression of BDNF in the hippocampus and frontal cortex and countermand the corticosterone-induced reduction in the BDNF expression in the cortical regions [105].

The dopamine complexed neurotoxin, 1-methyl-4-phenyl-1,2,3,6-tetrahydropyridine (MPTP) is metabolically transformed into 1-methyl-4-phenylpyridinium $\left(\mathrm{MPP}^{+}\right)$via $\mathrm{MAO}-$ $B$, which has been suggested to induce neuronal loss by altering the mitochondrial permeability [106]. The effects of $\mathrm{MPP}^{+}$on differentiated PC12 cells were also reported and outlined that MAOIs decrease $\mathrm{MMP}^{+}$-catalyzed nuclear fragmentation and reversed the decline in mitochondrial membrane potential, ROS generation, cytochrome $\mathrm{C}$ release, exhaustion of total glutathione extents, and neuronal death caused by $\mathrm{H}_{2} \mathrm{O}_{2}$.

The neural cell adhesion molecule L1CAM (L1) performs a crucial function in the growth of the central nervous system and is believed to be associated with multiple neurodegenerative disorders like AD [107]. In spinal cord injury, L1 can induce axonal regeneration and increase remyelination, neuronal survival, and synaptic plasticity [108]. In an experimental study, researchers suggested that MAOIs was an L1-mimetic as it enhances the expression and proteolysis of L1 and phosphorylation of extracellular-signal- 
regulated-kinase (Erk) caudal to the injured site. In another research, it was observed that MAOIs prevented the toxicity induced by the environmental neurotoxin paraquat- it was indicated that such drugs counteracted the decline in dopamine levels and tyrosine hydroxylase expression, decreased ROS formation, maintained mitochondrial viability, supported the antioxidant system, and averted a reduction in adenosine triphosphate (ATP) levels.

Phosphorylation of Fas-associated death domain (FADD), and death receptor mediator, can cause induction of anti-apoptotic activities [109]. It has been outlined that short-term exposure to MAOIs in animal models determines a noticeable incline in the proportion of phosphorylated to non-phosphorylated FADD in the cortical region, and the researchers proposed that this anti-apoptotic action of MAOIs could be associated with its GABAraising function, following stimulation of GABA-A receptors.

In metabolomics investigations, it was also indicated that i.p. administration to male rats of MAOI causes a noticeable incline in cortical levels of ornithine and a range of $\mathrm{N}$-acetylamino acids. It was reported that the enhanced levels of ornithine may be a marker of reduced production of polyamines or glutamate (consequently reduced generation of reactive aldehydes like acrolein), hence providing neuroprotection. The potential participation of the actions on $\mathrm{N}$-acetylated amino acids in neuroprotection requires a further understanding of the role these $\mathrm{N}$-acetylated amino acids have in the brain, though the occurrence in minute concentrations in CNS and is an indicator for viable neurons [110].

Table 2 describes the MAO inhibitors used in the preclinical trials for the treatment of Alzheimer's disease.

Table 2. Monoamine oxidase inhibitors in the preclinical trials for the treatment of Alzheimer's disease.

\begin{tabular}{|c|c|c|c|c|}
\hline Drug & Category of the Drug & Mechanism of Action & $\begin{array}{l}\text { Clinical } \\
\text { Phase }\end{array}$ & Ref. \\
\hline Ladostigil & $\begin{array}{l}\text { Inhibitor of monoamine } \\
\text { oxidases A and B }\end{array}$ & $\begin{array}{l}\text { Prevention of age-related glial } \\
\text { activation and spatial memory } \\
\text { deficits } \\
\text { Improvement of cognitive } \\
\text { performance } \\
\text { Modulation of amyloid precursor } \\
\text { protein processing } \\
\text { Upregulation of antioxidant } \\
\text { activity and mRNA expression of } \\
\text { antioxidant enzymes. }\end{array}$ & Phase 2 & [111] \\
\hline Selegiline & $\begin{array}{c}\text { Selective and } \\
\text { irreversible inhibitor of } \\
\text { monoamine oxidase B }\end{array}$ & $\begin{array}{c}\text { Regulation of cleavage of amyloid } \\
\text { precursor protein } \\
\text { Activation of phosphokinase C } \\
\text { Inhibits amyloid-beta plaque } \\
\text { formation } \\
\text { antioxidant. }\end{array}$ & Phase 3 & {$[42,112]$} \\
\hline Rasagiline & $\begin{array}{l}\text { Irreversible inhibitor of } \\
\text { monoamine oxidase B }\end{array}$ & $\begin{array}{l}\text { Modulates amyloid precursor } \\
\text { protein and amyloid-beta } \\
\text { processing } \\
\text { Iron chelator } \\
\text { Regulates the cell cycle }\end{array}$ & Phase 2 & [113] \\
\hline M-30 & $\begin{array}{c}\text { Inhibitor of monoamine } \\
\text { oxidases A and B } \\
\text { Iron chelator }\end{array}$ & $\begin{array}{l}\text { Regulates proteolytic processing of } \\
\text { amyloid precursor protein } \\
\text { Iron chelator } \\
\text { Reduces neuronal death and } \\
\text { apoptotic DNA damage }\end{array}$ & $\begin{array}{l}\text { Preclinical and clinical } \\
\text { phase }\end{array}$ & [114] \\
\hline
\end{tabular}




\section{Therapeutic Potential of Monoamine Oxidase Inhibitors in Multiple Neurodegenerative Diseases}

A broad variety of monoamine oxidase inhibitors (MAOIs) that comprises irreversible and reversible inhibitors of MAO-A, MAO-B, or both are available now, which prove to have the therapeutic advantage in various disorders such as stroke, neurodegenerative disorders, and aging. The therapeutic potential of MAOIs in distinct neurodegenerative disorders is explained hereunder; MAOIs have been therapeutically used for years in the treatment of depression [115]. The antidepressant effects of MAOIs are due to selective neuronal inhibition of MAO-A, which enhances the levels of dopamine in the CNS. The reversible MAO-A inhibitors have been proved to be specifically potent in the treatment of depression in aged patients [116].

Selective MAO-A and non-selective MAOIs came across as therapeutically active in the treatment of phobia and atypical depressions, like those including bulimia, hysterical traits, hypersomnia, tiredness for which they are better than amine-uptake inhibitors. MAO-B inhibitors lack the antidepressant property $[117,118]$ and do not assist the chain reaction except when administered at doses sufficient to inhibit MAO-A. The application of MAOIs as dopamine-sparing drugs or as adjuvants to levodopa was examined for the treatment of Parkinson's disease (PD), but such an approach with non-selective inhibitors was rejected. MAO-B levels are enhanced in the brains of patients with Parkinson's disease as a result of gliosis, since the human basal ganglia have elevated MAO-B than MAO-A expression, and because dopamine is uniformly metabolized by both isoenzymes in humans, the selective MAO-B inhibitor selegiline was earliest examined as an adjunct to levodopa. Selegiline is efficacious both as monotherapy and as an adjuvant to levodopa [119].

However, selegiline was shown to delay disease advancement during the initial stages of the treatment, no suggestive action on the course of the disease was located after that time [120]. Current indications propose that rasagiline and lazabemide can also slow the progression of Parkinson's disease [121]. Although, a contemporary study of the available evidence has deduced that there is inadequate data to suggest that any MAO-B inhibitor considerably slows early disease progression and that more study is needed. Initial research on the activity of MAO-B inhibitors on patients with PD was disturbed by the use of insufficient washout periods. Moreover, MAO-B inhibitors can relieve the symptoms of the disease to a certain extent; failure to consider this data might clear the somewhat overenthusiastic explanation of initial clinical results [122]. The pathways underlying these symptoms are not completely acknowledged, but MAO-B inhibition and increased levels of dopamine and 2-phenylethylamine (2-PEA) in the brain have been suggested to play a role. Nevertheless, inhibition of neither MAO-A nor MAO-B influences the equilibrium of central dopamine levels: only when both isoenzymes are inhibited does dopamine expression increase. 2-PEA, which has a similar physiological activity to amphetamine in its potential to release dopamine, has been regarded to be the internal amphetamine [123]. Its brain levels increase significantly following MAO-B inhibition, and the activity of aromatic l-amino acid oxidase is also enhanced [124]. It has been proposed that these effects might contribute to the evident neuroprotective effects of $\mathrm{MAO}-\mathrm{B}$ inhibitors. However, moclobemide, a selective reversible MAO-A inhibitor, has been indicated to possess anti-parkinsonian activity [125]. Clinical trials with selegiline in patients with Alzheimer's disease have not given definite outcomes, though MAO-B expression is enhanced in the brains of such cases and might increase oxidative stress in this disease [32].

Moreover, it has been suggested that multitherapy with a MAO-B inhibitor and one of the clinically used cholinesterase inhibitors, such as physostigmine, might be advantageous. A corresponding technique is to merge these 2 enzyme inhibitory functions in the same molecule. For example, the drug ladostigil combines the pharmacophore of rasagiline and a carbamate cholinesterase inhibitory moiety. Its therapeutic actions involve neuroprotection, butyrylcholinesterase and acetylcholinesterase inhibition, and brain-selective MAOA/B inhibition [126]. It seems to be potential in increasing cognition in humans, as well as having 
antidepressant and anxiolytic activity [127] and is in clinical trials for Alzheimer's disease at present. Other neurodegenerative diseases such as Huntington's disease, schizophrenia, and amyotrophic lateral sclerosis (ALS) share multiple pathological characteristics with Parkinson's disease and Alzheimer's disease, like oxidative stress, iron accumulation, excitotoxicity, neuroinflammation, and the misfolding of toxic proteins that cannot be degraded after ubiquitination. Selegiline treatment has not proved to be beneficial in the therapy of ALS. Although, rasagiline and CGP 3466 have been reported to be efficacious in animal models of ALS [128]. A single-patient study has reported successful use of selegiline, in combination with the serotonin reuptake inhibitor fluoxetine, in Huntington's disease [18].

\section{Future Perspectives}

Investigations on MAO and its inhibitors have devoted considerably to our comprehension of aminergic neurotransmission. They contributed to the literature suggesting that MAO plays a crucial role in normal brain physiology, and its inhibitors have established a pivotal place in depression and parkinsonism drug therapy. Moreover, they have delivered extra momentum in the advancement of several enzyme inhibitors as therapeutic targets in the treatment of Alzheimer's disease and Parkinson's disease, along with the combination of distinct inhibitory effects in a solitary moiety. Although, there is still not a complete understanding of their neuroprotective functions, neither is it indicated whether these drugs are adequately efficacious in the aged individual to merit their long-term use in the treatment of neurodegenerative disorders.

As previously mentioned, this unpredictability is correlated with limitations in the conduction of experimental studies, possibly aggravated by a bit random dosage preference. Though, the long-term safety of selegiline has now been well-established. Some MAO inhibitors and structurally related compounds are "in the pipeline" and are the subject of various clinical/preclinical studies. Among them, the propargyl amines can be mentioned (i.e., rasagiline which has been observed to be useful in an experimental model of amyotrophic lateral sclerosis); as well, it could be used in the treatment of multiple neurological diseases.

A range of aliphatic propargyl amines has also been proven to be potent neuroprotective compounds in various in vivo and in vitro animal models. The aldehyde-sequestering functions of phenelzine propose that several congeners of this compound should be scrutinized as possible neuroprotective drugs. By altering the sequence of an alkyl chain, the GABA-inhibiting action (MAO-inhibiting effect) of phenelzine can be adjusted while still preserving the aldehyde-sequestering activity.

Preclinical research concerning the structure-activity relationships might then be directed to govern the respective significance of sequestering reactive aldehydes. The newly discovered MAOIs were found efficacious and less toxic, though would not be able to locate a potent and specific MAOI that can selectively be used in the treatment of AD. Uncovering the crystal structures of MAO isoforms has largely supported the comprehension of drugreceptor interactions at the molecular level. The ligand-based rational-drug design of specific MAOIs has intensified the synthesis of novel leads. Consequently, from now onwards the synthesis of potent MAOIs via rational-drug-design approaches and the development of novel MAOIs may assist to acknowledge drug-receptor interaction and develop potential therapeutic compounds in the treatment of AD.

Various newly developed MAOI compounds could be further expanded to decrease their probable adverse effects as promised candidates for AD therapy. Computational and synthetic chemistry are the methods for synthesizing ligands with potential MAO inhibiting properties. In the future, it is considered that evaluated and assembled data in this review will accelerate objectives for designing novel MAOIs in the treatment of AD. 


\section{Conclusions}

Neurodegenerative disorders, mainly Alzheimer's disease (AD), imply an immense economical and psychological load on humankind all over the globe. Age-linked AD is catalyzed through multiple factors, one of which is the overactive MAO enzyme, which metabolizes several amine neurotransmitters and generates several neurotoxic end-products such as reactive aldehydes, hydrogen peroxide, thus contributing to the development of $\mathrm{AD}$. Hence, $\mathrm{MAO}$ was considered as a requisite drug target in the treatment of $\mathrm{AD}$ and its inhibitors have largely granted our understanding of aminergic neurotransmission. The MAOIs persist to be under substantial attention and the concern of considerable exploration. Many of them may prove to be beneficial in the treatment of some neurodegenerative diseases, ischemic stroke, and drug abuse, either single or as supplementary drugs. In actual fact, their multi-sided actions could be a privilege, providing them suitability to be used in the treatment of various disorders. Studies to date have reported that the neuroprotective effects of these drugs are composite and, in some cases are independent of MAO inhibition. They continue to be useful pharmacological agents that have done great to enhance our understanding of pathways complexed with neuroprotection and have stated major indications for future progression of neuroprotective agents.

Author Contributions: Conceptualization, T.B., D.K., A.S., S.S. and N.S.; Data curation, T.B., D.K., A.S., S.S., N.S., G.Z., F.L.A.-C., M.M.T. Formal analysis, T.B. and S.B.; Investigation, T.B., D.K., A.S., S.S., N.S., G.Z., F.L.A.-C., M.M.T.; Methodology, T.B. and S.B.; Supervision, T.B., S.B. and A.G.B.; Validation, T.B., S.B. and A.G.B.; Visualization, S.B.; Writing—original draft, T.B., D.K., A.S., S.S. and N.S.; Writing - review and editing, T.B, S.B. and A.G.B. All authors have equal contribution to the first author. All authors have read and agreed to the published version of the manuscript.

Funding: This article received no external funding.

Institutional Review Board Statement: Not applicable.

Informed Consent Statement: Not applicable.

Conflicts of Interest: The authors declare no conflict of interest.

\section{References}

1. Alzheimer's Association. Alzheimer's disease facts and figures. Alzheimers Dement. 2015, 11, 332-384.

2. McKhann, G.M.; Knopman, D.S.; Chertkow, H.; Hyman, B.T.; Jack, C.R., Jr.; Kawas, C.H.; Klunk, W.E.; Koroshetz, W.J.; Manly, J.J.; Mayeux, R. The diagnosis of dementia due to Alzheimer's disease: Recommendations from the National Institute on Aging-Alzheimer's Association workgroups on diagnostic guidelines for Alzheimer's disease. Alzheimer's Dement. 2011, 7, 263-269. [CrossRef] [PubMed]

3. Prince, M.; Wimo, A.; Guerchet, M.; Ali, G.-C.; Wu, Y.-T.; Prina, M. World Alzheimer Report; Alzheimer's Disease International: London, UK, 2013.

4. Wyss-Coray, T. Inflammation in Alzheimer disease: Driving force, bystander or beneficial response? Nat. Med. 2006, 12, 1005-1015. [PubMed]

5. Avila-Muñoz, E.; Arias, C. When astrocytes become harmful: Functional and inflammatory responses that contribute to Alzheimer's disease. Ageing Res. Rev. 2014, 18, 29-40. [CrossRef] [PubMed]

6. Sofroniew, M.V. Molecular dissection of reactive astrogliosis and glial scar formation. Trends Neurosci. 2009, 32, 638-647. [CrossRef] [PubMed]

7. Meraz Rios, M.A.; Toral-Rios, D.; Franco-Bocanegra, D.; Villeda-Hernández, J.; Campos-Peña, V. Inflammatory process in Alzheimer's Disease. Front. Integr. Neurosci. 2013, 7, 59. [CrossRef]

8. Cohen, G.; Kesler, N. Monoamine oxidase and mitochondrial respiration. J. Neurochem. 1999, 73, 2310-2315. [CrossRef] [PubMed]

9. Cai, Z. Monoamine oxidase inhibitors: Promising therapeutic agents for Alzheimer's disease. Mol. Med. Rep. 2014, 9, 1533-1541. [CrossRef] [PubMed]

10. Thomas, T. Monoamine oxidase-B inhibitors in the treatment of Alzheimers disease. Neurobiol. Aging 2000, 21, 343-348. [CrossRef]

11. Youdim, M.; Riederer, P. The relevance of glial monoamine oxidase-B and polyamines to the action of selegiline in parkinson's disease. Mov. Disord. 1993, 8, S8-S13. [CrossRef] [PubMed]

12. Emilsson, L.; Saetre, P.; Balciuniene, J.; Castensson, A.; Cairns, N.; Jazin, E.E. Increased monoamine oxidase messenger RNA expression levels in frontal cortex of Alzheimer's disease patients. Neurosci. Lett. 2002, 326, 56-60. [CrossRef] 
13. Gulyás, B.; Pavlova, E.; Kása, P.; Gulya, K.; Bakota, L.; Várszegi, S.; Keller, É.; Horváth, M.C.; Nag, S.; Hermecz, I. Activated MAO$\mathrm{B}$ in the brain of Alzheimer patients, demonstrated by (1C)-L-deprenyl using whole hemisphere autoradiography. Neurochem. Int. 2011, 58, 60-68. [CrossRef]

14. Rahman, K. Studies on free radicals, antioxidants, and co-factors. Clin. Interv. Aging 2007, 2, 219.

15. Carter, S.F.; Schöll, M.; Almkvist, O.; Wall, A.; Engler, H.; Långström, B.; Nordberg, A. Evidence for astrocytosis in prodromal Alzheimer disease provided by 11C-deuterium-L-deprenyl: A multitracer PET paradigm combining 11C-Pittsburgh compound B and 18F-FDG. J. Nucl. Med. 2012, 53, 37-46. [CrossRef]

16. Sano, M.; Ernesto, C.; Thomas, R.G.; Klauber, M.R.; Schafer, K.; Grundman, M.; Woodbury, P.; Growdon, J.; Cotman, C.W.; Pfeiffer, E. A controlled trial of selegiline, alpha-tocopherol, or both as treatment for Alzheimer's disease. N. Engl. J. Med. 1997, 336, 1216-1222. [CrossRef]

17. Magni, G.; Meibach, R. Lazabemide for the long-term treatment of Alzheimer's disease. Eur. Neuropsychopharmacol. 1999, $9,142$. [CrossRef]

18. Youdim, M.B.; Edmondson, D.; Tipton, K.F. The therapeutic potential of monoamine oxidase inhibitors. Nat. Rev. Neurosci. 2006, 7, 295-309. [CrossRef] [PubMed]

19. Tripathi, A.C.; Upadhyay, S.; Paliwal, S.; Saraf, S.K. Privileged scaffolds as MAO inhibitors: Retrospect and prospects. Eur. J. Med. Chem. 2018, 145, 445-497. [CrossRef]

20. Ramsay, R.R. Monoamine oxidases: The biochemistry of the proteins as targets in medicinal chemistry and drug discovery. Curr. Top. Med. Chem. 2012, 12, 2189-2209. [CrossRef]

21. Yoshimoto, M.; Hirata, M.; Kagawa, S.; Magata, Y.; Ohmomo, Y.; Temma, T. Synthesis and characterization of novel radiofluorinated probes for positron emission tomography imaging of monoamine oxidase B. J. Label. Compd. Radiopharm. 2019, 62, 580-587. [CrossRef]

22. McDonald, G.R.; Olivieri, A.; Ramsay, R.R.; Holt, A. On the formation and nature of the imidazoline I2 binding site on human monoamine oxidase-B. Pharmacol. Res. 2010, 62, 475-488. [CrossRef]

23. Edmondson, E.D. Hydrogen peroxide produced by mitochondrial monoamine oxidase catalysis: Biological implications. Curr. Pharm. Des. 2014, 20, 155-160. [CrossRef]

24. Fitzpatrick, P.F. Oxidation of amines by flavoproteins. Arch. Biochem. Biophys. 2010, 493, 13-25. [CrossRef]

25. Reyes-Parada, M.; Fierro, A.; Iturriaga-Vasquez, P.; Cassels, B.K. Monoamine oxidase inhibition in the light of new structural data. Curr. Enzym. Inhib. 2005, 1, 85-95. [CrossRef]

26. Binda, C.; Wang, J.; Pisani, L.; Caccia, C.; Carotti, A.; Salvati, P.; Edmondson, D.E.; Mattevi, A. Structures of human monoamine oxidase B complexes with selective noncovalent inhibitors: Safinamide and coumarin analogs. J. Med. Chem. 2007, 50, 5848-5852. [CrossRef] [PubMed]

27. Kumar, B.; Mantha, A.K.; Kumar, V. Recent developments on the structure-activity relationship studies of MAO inhibitors and their role in different neurological disorders. RSC Adv. 2016, 6, 42660-42683. [CrossRef]

28. Son, S.-Y.; Ma, J.; Kondou, Y.; Yoshimura, M.; Yamashita, E.; Tsukihara, T. Structure of human monoamine oxidase A at 2.2- $\AA$ resolution: The control of opening the entry for substrates/inhibitors. Proc. Natl. Acad. Sci. USA 2008, 105, 5739-5744. [CrossRef]

29. De Colibus, L.; Li, M.; Binda, C.; Lustig, A.; Edmondson, D.E.; Mattevi, A. Three-Dimensional structure of human monoamine oxidase A (MAO A): Relation to the structures of rat MAO A and human MAO B. Proc. Natl. Acad. Sci. USA 2005, 102, 12684-12689. [CrossRef]

30. Hong, R.; Li, X. Discovery of monoamine oxidase inhibitors by medicinal chemistry approaches. MedChemComm 2019, 10, 10-25. [CrossRef] [PubMed]

31. Barner, E.L.; Gray, S.L. Donepezil use in Alzheimer disease. Ann. Pharmacother. 1998, 32, 70-77. [CrossRef]

32. Kennedy, B.; Ziegler, M.; Alford, M.; Hansen, L.; Thal, L.; Masliah, E. Early and persistent alterations in prefrontal cortex MAO A and B in Alzheimer's disease. J. Neural Transm. 2003, 110, 789-801. [CrossRef]

33. Burke, W.J.; Li, S.W.; Schmitt, C.A.; Xia, P.; Chung, H.D.; Gillespie, K.N. Accumulation of 3, 4-dihydroxyphenylglycolaldehyde, the neurotoxic monoamine oxidase A metabolite of norepinephrine, in locus ceruleus cell bodies in Alzheimer's disease: Mechanism of neuron death. Brain Res. 1999, 816, 633-637. [CrossRef]

34. Chan-Palay, V.; Höchli, M.; Savaskan, E.; Hungerecker, G. Calbindin D-28k and monoamine oxidase A immunoreactive neurons in the nucleus basalis of Meynert in senile dementia of the Alzheimer type and Parkinson's disease. Dement. Geriatr. Cogn. Disord. 1993, 4, 1-15. [CrossRef] [PubMed]

35. Danilova, R.; Moskvityna, T.; Obukhova, M.; Belopolskaya, M.; Ashmarin, I. Pargyline conjugate-induced long-term activation of monoamine oxidase as an immunological model for depression. Neurochem. Res. 1999, 24, 1147-1151. [CrossRef]

36. Kumagae, Y.; Matsui, Y.; Iwata, N. Deamination of norepinephrine, dopamine, and serotonin by type A monoamine oxidase in discrete regions of the rat brain and inhibition by RS-8359. Jpn. J. Pharmacol. 1991, 55, 121-128. [CrossRef]

37. Moret, C.; Briley, M. The importance of norepinephrine in depression. Neuropsychiatr. Dis. Treat. 2011, 7,9.

38. Grailhe, R.; Cardona, A.; Even, N.; Seif, I.; Changeux, J.-P.; Cloëz-Tayarani, I. Regional changes in the cholinergic system in mice lacking monoamine oxidase A. Brain Res. Bull. 2009, 78, 283-289. [CrossRef]

39. Schneier, F.R. Pharmacotherapy of social anxiety disorder. Expert Opin. Pharm. 2011, 12, 615-625. [CrossRef]

40. Dhull, D.K.; Jindal, A.; Dhull, R.K.; Aggarwal, S.; Bhateja, D.; Padi, S.S. Neuroprotective effect of cyclooxygenase inhibitors in ICV-STZ induced sporadic Alzheimer's disease in rats. J. Mol. Neurosci. 2012, 46, 223-235. [CrossRef] 
41. Muck-Seler, D.; Presecki, P.; Mimica, N.; Mustapic, M.; Pivac, N.; Babic, A.; Nedic, G.; Folnegovic-Smalc, V. Platelet serotonin concentration and monoamine oxidase type B activity in female patients in early, middle and late phase of Alzheimer's disease. Prog. Neuro Psychopharmacol. Biol. Psychiatry 2009, 33, 1226-1231. [CrossRef]

42. Bar-Am, O.; Amit, T.; Weinreb, O.; Youdim, M.B.; Mandel, S. Propargylamine containing compounds as modulators of proteolytic cleavage of amyloid protein precursor: Involvement of MAPK and PKC activation. J. Alzheimer's Dis. 2010, 21, 361-371. [CrossRef] [PubMed]

43. Cochet, M.; Donneger, R.; Cassier, E.; Gaven, F.; Lichtenthaler, S.F.; Marin, P.; Bockaert, J.; Dumuis, A.; Claeysen, S. 5-HT4 receptors constitutively promote the non-amyloidogenic pathway of APP cleavage and interact with ADAM10. ACS Chem. Neurosci. 2013, 4, 130-140. [CrossRef] [PubMed]

44. Kim, D.; Baik, S.H.; Kang, S.; Cho, S.W.; Bae, J.; Cha, M.-Y.; Sailor, M.J.; Mook-Jung, I.; Ahn, K.H. Close correlation of monoamine oxidase activity with progress of Alzheimer's disease in mice, observed by in vivo two-photon imaging. ACS Cent. Sci. 2016, 2, 967-975. [CrossRef] [PubMed]

45. Streit, W.J. Microglial activation and neuroinflammation in Alzheimer's disease: A critical examination of recent history. Front. Aging Neurosci. 2010, 2, 22. [CrossRef]

46. Saura, J.; Luque, J.; Cesura, A.; Da Prada, M.; Chan-Palay, V.; Huber, G.; Löffler, J.; Richards, J. Increased monoamine oxidase B activity in plaque-associated astrocytes of Alzheimer brains revealed by quantitative enzyme radioautography. Neuroscience 1994, 62, 15-30. [CrossRef]

47. Jossan, S.; Gillberg, P.; Gottfries, C.; Karlsson, I.; Oreland, L. Monoamine oxidase B in brains from patients with Alzheimer's disease: A biochemical and autoradiographical study. Neuroscience 1991, 45, 1-12. [CrossRef]

48. Novaroli, L.; Reist, M.; Favre, E.; Carotti, A.; Catto, M.; Carrupt, P.-A. Human recombinant monoamine oxidase B as reliable and efficient enzyme source for inhibitor screening. Bioorg. Med. Chem. 2005, 13, 6212-6217. [CrossRef]

49. Schedin-Weiss, S.; Inoue, M.; Hromadkova, L.; Teranishi, Y.; Yamamoto, N.G.; Wiehager, B.; Bogdanovic, N.; Winblad, B.; Sandebring-Matton, A.; Frykman, S. Monoamine oxidase B is elevated in Alzheimer disease neurons, is associated with $\gamma-$ secretase and regulates neuronal amyloid $\beta$-peptide levels. Alzheimers Res. Ther. 2017, 9, 1-19. [CrossRef]

50. Quartey, M.O.; Nyarko, J.N.; Pennington, P.R.; Heistad, R.M.; Klassen, P.C.; Baker, G.B.; Mousseau, D.D. Alzheimer disease and selected risk factors disrupt a co-regulation of monoamine oxidase-A/B in the hippocampus, but not in the cortex. Front. Neurosci. 2018, 12, 419. [CrossRef]

51. Park, J.-H.; Ju, Y.H.; Choi, J.W.; Song, H.J.; Jang, B.K.; Woo, J.; Chun, H.; Kim, H.J.; Shin, S.J.; Yarishkin, O. Newly developed reversible MAO-B inhibitor circumvents the shortcomings of irreversible inhibitors in Alzheimer's disease. Sci. Adv. 2019, 5, eaav0316. [CrossRef]

52. Borroni, E.; Bohrmann, B.; Grueninger, F.; Prinssen, E.; Nave, S.; Loetscher, H.; Chinta, S.J.; Rajagopalan, S.; Rane, A.; Siddiqui, A. Sembragiline: A novel, selective monoamine oxidase type B inhibitor for the treatment of Alzheimer's disease. J. Pharmacol. Exp. Ther. 2017, 362, 413-423. [CrossRef]

53. Lam, R.W.; Milev, R.; Rotzinger, S.; Andreazza, A.C.; Blier, P.; Brenner, C.; Daskalakis, Z.J.; Dharsee, M.; Downar, J.; Evans, K.R. Discovering biomarkers for antidepressant response: Protocol from the Canadian biomarker integration network in depression (CAN-BIND) and clinical characteristics of the first patient cohort. BMC Psychiatry 2016, 16, 1-13. [CrossRef]

54. Marchitti, S.A.; Deitrich, R.A.; Vasiliou, V. Neurotoxicity and metabolism of the catecholamine-derived 3, 4-dihydroxyphenylacetaldehyde and 3, 4-dihydroxyphenylglycolaldehyde: The role of aldehyde dehydrogenase. Pharmacol. Rev. 2007, 59, 125-150. [CrossRef]

55. Cagle, B.S.; Crawford, R.A.; Doorn, J.A. Biogenic aldehyde-mediated mechanisms of toxicity in neurodegenerative disease. Curr. Opin. Toxicol. 2019, 13, 16-21. [CrossRef]

56. Tábi, T.; Vécsei, L.; Youdim, M.B.; Riederer, P.; Szökő, É. Selegiline: A molecule with innovative potential. J. Neural Transm. 2020, 127, 831-842. [CrossRef]

57. Riederer, P.; Danielczyk, W.; Grünblatt, E. Monoamine oxidase-B inhibition in Alzheimer's disease. Neurotoxicology 2004, 25, 271-277. [CrossRef]

58. Zheng, H.; Fridkin, M.; Youdim, M.B. Site-Activated chelators derived from anti-Parkinson drug rasagiline as a potential safer and more effective approach to the treatment of Alzheimer's disease. Neurochem. Res. 2010, 35, 2117-2123. [CrossRef]

59. Weinreb, O.; Mandel, S.; Bar-Am, O.; Amit, T. Iron-Chelating backbone coupled with monoamine oxidase inhibitory moiety as novel pluripotential therapeutic agents for Alzheimer's disease: A tribute to Moussa Youdim. J. Neural Transm. 2011, 118, 479-492. [CrossRef]

60. Wang, L.; Esteban, G.; Ojima, M.; Bautista-Aguilera, O.M.; Inokuchi, T.; Moraleda, I.; Iriepa, I.; Samadi, A.; Youdim, M.B.; Romero, A. Donepezil+ propargylamine+ 8-hydroxyquinoline hybrids as new multifunctional metal-chelators, ChE and MAO inhibitors for the potential treatment of Alzheimer's disease. Eur. J. Med. Chem. 2014, 80, 543-561. [CrossRef]

61. Wood, P.L. Neurodegeneration and aldehyde load: From concept to therapeutics. J. Psychiatry Neurosci. JPN 2006, 31, 296.

62. Thanh Nam, D.; Arseneault, M.; Murthy, V.; Ramassamy, C. Potential role of acrolein in neurodegeneration and in Alzheimer's disease. Curr. Mol. Pharmacol. 2010, 3, 66-78. [CrossRef]

63. Romano, A.; Serviddio, G.; Calcagnini, S.; Villani, R.; Giudetti, A.M.; Cassano, T.; Gaetani, S. Linking lipid peroxidation and neuropsychiatric disorders: Focus on 4-hydroxy-2-nonenal. Free Radic. Biol. Med. 2017, 111, 281-293. [CrossRef] [PubMed]

64. Taso, O.V.; Philippou, A.; Moustogiannis, A.; Zevolis, E.; Koutsilieris, M. Lipid peroxidation products and their role in neurodegenerative diseases. Ann. Res. Hosp. 2019, 3. [CrossRef] 
65. O'Brien, P.J.; Siraki, A.G.; Shangari, N. Aldehyde sources, metabolism, molecular toxicity mechanisms, and possible effects on human health. Crit. Rev. Toxicol. 2005, 35, 609-662. [CrossRef] [PubMed]

66. Abdel-Daim, M.M.; Abo-EL-Sooud, K.; Aleya, L.; Bungău, S.G.; Najda, A.; Saluja, R. Alleviation of drugs and chemicals toxicity: Biomedical value of antioxidants. Oxid. Med. Cell. Longev. 2018, 2018. [CrossRef] [PubMed]

67. Wood, P.L.; Wood, J.A. Thiol metabolism in schizophrenia: Current status. Curr. Psychiatry Rev. 2013, 9, 136-147. [CrossRef]

68. Gustaw-Rothenberg, K.; Kowalczuk, K.; Stryjecka-Zimmer, M. Lipids' peroxidation markers in Alzheimer's disease and vascular dementia. Geriatr. Gerontol. Int. 2010, 10, 161-166. [CrossRef]

69. Sinem, F.; Dildar, K.; Gokhan, E.; Melda, B.; Orhan, Y.; Filiz, M. The serum protein and lipid oxidation marker levels in Alzheimer's disease and effects of cholinesterase inhibitors and antipsychotic drugs therapy. Curr. Alzheimer Res. 2010, 7, 463-469. [CrossRef]

70. Moghe, A.; Ghare, S.; Lamoreau, B.; Mohammad, M.; Barve, S.; McClain, C.; Joshi-Barve, S. Molecular mechanisms of acrolein toxicity: Relevance to human disease. Toxicol. Sci. 2015, 143, 242-255. [CrossRef]

71. Khoramjouy, M.; Naderi, N.; Kobarfard, F.; Heidarli, E.; Faizi, M. An intensified acrolein exposure can affect memory and cognition in rat. Neurotox. Res. 2021, 39, 277-291. [CrossRef]

72. Huang, Y.-J.; Jin, M.-H.; Pi, R.-B.; Zhang, J.-J.; Ouyang, Y.; Chao, X.-J.; Chen, M.-H.; Liu, P.-Q.; Yu, J.-C.; Ramassamy, C. Acrolein induces Alzheimer's disease-like pathologies in vitro and in vivo. Toxicol. Lett. 2013, 217, 184-191. [CrossRef]

73. Li, X.-H.; Xie, J.-Z.; Jiang, X.; Lv, B.-L.; Cheng, X.-S.; Du, L.-L.; Zhang, J.-Y.; Wang, J.-Z.; Zhou, X.-W. Methylglyoxal induces tau hyperphosphorylation via promoting AGEs formation. Neuromol. Med. 2012, 14, 338-348. [CrossRef]

74. Bradley, M.; Markesbery, W.; Lovell, M. Increased levels of 4-hydroxynonenal and acrolein in the brain in preclinical Alzheimer disease. Free Radic. Biol. Med. 2010, 48, 1570-1576. [CrossRef]

75. Baker, G.; Matveychuk, D.; MacKenzie, E.M.; Holt, A.; Wang, Y.; Kar, S. Attenuation of the effects of oxidative stress by the MAO-inhibiting antidepressant and carbonyl scavenger phenelzine. Chem. Biol. Interact. 2019, 304, 139-147. [CrossRef]

76. Elhelaly, A.E.; AlBasher, G.; Alfarraj, S.; Almeer, R.; Bahbah, E.I.; Fouda, M.M.A.; Bungau, S.G.; Aleya, L.; Abdel-Daim, M.M. Protective effects of hesperidin and diosmin against acrylamide-induced liver, kidney, and brain oxidative damage in rats. Environ. Sci. Pollut. Res. 2019, 26, 35151-35162. [CrossRef]

77. Singh, I.N.; Gilmer, L.K.; Miller, D.M.; Cebak, J.E.; Wang, J.A.; Hall, E.D. Phenelzine mitochondrial functional preservation and neuroprotection after traumatic brain injury related to scavenging of the lipid peroxidation-derived aldehyde 4-hydroxy-2nonenal. J. Cereb. Blood Flow Metab. 2013, 33, 593-599. [CrossRef]

78. Mustafa, A.G.; Alfaqih, M.A.; Al-Shboul, O. The 4-hydroxynonenal mediated oxidative damage of blood proteins and lipids involves secondary lipid peroxidation reactions. Exp. Ther. Med. 2018, 16, 2132-2137. [CrossRef]

79. MacKenzie, E.M.; Song, M.-S.; Dursun, S.M.; Tomlinson, S.; Todd, K.G.; Baker, G.B. Phenelzine: An old drug that may hold clues to the development of new neuroprotective agents. Klin. Psikofarmakol. Bül. Bull. Clin. Psychopharmacol. 2010, 20, 179-186. [CrossRef]

80. Matveychuk, D.; Nunes, E.; Ullah, N.; Velázquez-Martinez, C.A.; MacKenzie, E.M.; Baker, G.B. Comparison of phenelzine and geometric isomers of its active metabolite, $\beta$-phenylethylidenehydrazine, on rat brain levels of amino acids, biogenic amine neurotransmitters and methylamine. J. Neural Transm. 2013, 120, 987-996. [CrossRef]

81. Paslawski, T.; Knaus, E.; Iqbal, N.; Coutts, R.; Baker, G. $\beta$-phenylethylidenehydrazine, a novel inhibitor of GABA transaminase. Drug Dev. Res. 2001, 54, 35-39. [CrossRef]

82. Leker, R.; Neufeld, M. Anti-epileptic drugs as possible neuroprotectants in cerebral ischemia. Brain Res. Rev. 2003, 42, 187-203. [CrossRef]

83. Stumm, R.K.; Culmsee, C.; Schäfer, M.K.-H.; Krieglstein, J.; Weihe, E. Adaptive plasticity in tachykinin and tachykinin receptor expression after focal cerebral ischemia is differentially linked to gabaergic and glutamatergic cerebrocortical circuits and cerebrovenular endothelium. J. Neurosci. 2001, 21, 798-811. [CrossRef] [PubMed]

84. Cohen, S.M.; Tsien, R.W.; Goff, D.C.; Halassa, M.M. The impact of NMDA receptor hypofunction on GABAergic neurons in the pathophysiology of schizophrenia. Schizophr. Res. 2015, 167, 98-107. [CrossRef] [PubMed]

85. Foerster, B.R.; Pomper, M.G.; Callaghan, B.C.; Petrou, M.; Edden, R.A.; Mohamed, M.A.; Welsh, R.C.; Carlos, R.C.; Barker, P.B.; Feldman, E.L. An imbalance between excitatory and inhibitory neurotransmitters in amyotrophic lateral sclerosis revealed by use of 3-T proton magnetic resonance spectroscopy. JAMA Neurol. 2013, 70, 1009-1016. [CrossRef]

86. Kim, Y.S.; Yoon, B.-E. Altered GABAergic signaling in brain disease at various stages of life. Exp. Neurobiol. 2017, $26,122$. [CrossRef]

87. Potter, L.E.; Paylor, J.W.; Suh, J.S.; Tenorio, G.; Caliaperumal, J.; Colbourne, F.; Baker, G.; Winship, I.; Kerr, B.J. Altered excitatoryinhibitory balance within somatosensory cortex is associated with enhanced plasticity and pain sensitivity in a mouse model of multiple sclerosis. J. Neuroinflamm. 2016, 13, 1-20. [CrossRef]

88. Luscher, B.; Shen, Q.; Sahir, N. The GABAergic deficit hypothesis of major depressive disorder. Mol. Psychiatry 2011, 16, 383-406. [CrossRef]

89. Sowa, B.; Rauw, G.; Davood, A.; Fassihi, A.; Knaus, E.E.; Baker, G.B. Design and biological evaluation of phenyl-substituted analogs of $\beta$-phenylethylidenehydrazine. Bioorg. Med. Chem. 2005, 13, 4389-4395. [CrossRef]

90. Sowa, B.; Knaus, E.; Todd, K.; Davood, A.; Baker, G. Biochemical activity of 4-fluorophenylethyl-idenehydrazine and its potential as a neuroprotectant in cerebral ischemia. J. Neurochem. 2003, 85, 10. 
91. Shanahan, P.; O'Sullivan, J.; Tipton, K.F.; Kinsella, G.K.; Ryan, B.J.; Henehan, G.T. Theobromine and related methylxanthines as inhibitors of primary amine oxidase. J. Food Biochem. 2019, 43, e12697. [CrossRef]

92. Stolen, C.M.; Yegutkin, G.G.; Kurkijärvi, R.; Bono, P.; Alitalo, K.; Jalkanen, S. Origins of serum semicarbazide-sensitive amine oxidase. Circ. Res. 2004, 95, 50-57. [CrossRef]

93. Chen, K.; Maley, J.; Yu, P.H. Potential implications of endogenous aldehydes in $\beta$-amyloid misfolding, oligomerization and fibrillogenesis. J. Neurochem. 2006, 99, 1413-1424. [CrossRef] [PubMed]

94. Pannecoeck, R.; Serruys, D.; Benmeridja, L.; Delanghe, J.R.; Geel, N.V.; Speeckaert, R.; Speeckaert, M.M. Vascular adhesion protein-1: Role in human pathology and application as a biomarker. Crit. Rev. Clin. Lab. Sci. 2015, 52, 284-300. [CrossRef] [PubMed]

95. Unzeta, M.; Sole, M.; Boada, M.; Hernández, M. Semicarbazide-Sensitive amine oxidase (SSAO) and its possible contribution to vascular damage in Alzheimer's disease. J. Neural Transm. 2007, 114, 857-862. [CrossRef]

96. Valente, T.; Gella, A.; Solé, M.; Durany, N.; Unzeta, M. Immunohistochemical study of semicarbazide-sensitive amine oxidase/vascular adhesion protein-1 in the hippocampal vasculature: Pathological synergy of Alzheimer's disease and diabetes mellitus. J. Neurosci. Res. 2012, 90, 1989-1996. [CrossRef] [PubMed]

97. O'Rourke, A.; Wang, E.; Salter-Cid, L.; Huang, L.; Miller, A.; Podar, E.; Gao, H.; Jones, D.; Linnik, M. Benefit of inhibiting SSAO in relapsing experimental autoimmune encephalomyelitis. J. Neural Transm. 2007, 114, 845. [CrossRef] [PubMed]

98. Jarnicki, A.; Schilter, H.; Liu, G.; Wheeldon, K.; Essilfie, A.T.; Foot, J.; Yow, T.; Jarolimek, W.; Hansbro, P. The inhibitor of semicarbazide-sensitive amine oxidase, PXS-4728A, ameliorates key features of chronic obstructive pulmonary disease in a mouse model. Br. J. Pharmacol. 2016, 173, 3161-3175. [CrossRef]

99. Horváth, Á.; Menghis, A.; Botz, B.; Borbély, É.; Kemény, Á.; Tékus, V.; Csepregi, J.Z.; Mócsai, A.; Juhász, T.; Zákány, R. Analgesic and anti-inflammatory effects of the novel semicarbazide-sensitive amine-oxidase inhibitor SzV-1287 in chronic arthritis models of the mouse. Sci. Rep. 2017, 7, 1-13. [CrossRef]

100. Ma, Q.; Manaenko, A.; Khatibi, N.H.; Chen, W.; Zhang, J.H.; Tang, J. Vascular adhesion protein-1 inhibition provides antiinflammatory protection after an intracerebral hemorrhagic stroke in mice. J. Cereb. Blood Flow Metab. 2011, 31, 881-893. [CrossRef]

101. Mustafa, A.G.; Al-Shboul, O.; Alfaqih, M.A.; Al-Qudah, M.A.; Al-Dwairi, A.N. Phenelzine reduces the oxidative damage induced by peroxynitrite in plasma lipids and proteins. Arch. Physiol. Biochem. 2018, 124, 418-423. [CrossRef]

102. Bedard, K.; Krause, K.-H. The NOX family of ROS-generating NADPH oxidases: Physiology and pathophysiology. Physiol. Rev. 2007, 87, 245-313. [CrossRef] [PubMed]

103. Niemann, B.; Rohrbach, S.; Miller, M.R.; Newby, D.E.; Fuster, V.; Kovacic, J.C. Oxidative stress and cardiovascular risk: Obesity, diabetes, smoking, and pollution: Part 3 of a 3-part series. J. Am. Coll. Cardiol. 2017, 70, 230-251. [CrossRef] [PubMed]

104. Balu, D.T.; Hoshaw, B.A.; Malberg, J.E.; Rosenzweig-Lipson, S.; Schechter, L.E.; Lucki, I. Differential regulation of central BDNF protein levels by antidepressant and non-antidepressant drug treatments. Brain Res. 2008, 1211, 37-43. [CrossRef] [PubMed]

105. Dwivedi, Y.; Rizavi, H.S.; Pandey, G.N. Antidepressants reverse corticosterone-mediated decrease in brain-derived neurotrophic factor expression: Differential regulation of specific exons by antidepressants and corticosterone. Neuroscience 2006, 139, 1017-1029. [CrossRef]

106. Lee, C.S.; Han, E.S.; Lee, W.B. Antioxidant effect of phenelzine on MPP+-induced cell viability loss in differentiated PC12 cells. Neurochem. Res. 2003, 28, 1833-1841. [CrossRef]

107. Joseph, T.P.; Nataraj Jagadeesan, L.Y.S.; Lin, S.L.; Sahu, S.; Schachner, M. Adhesion molecule L1 agonist mimetics protect against the pesticide paraquat-induced locomotor deficits and biochemical alterations in zebrafish. Front. Neurosci. 2020, $14,458$. [CrossRef]

108. Li, R.; Sahu, S.; Schachner, M. Phenelzine, a cell adhesion molecule L1 mimetic small organic compound, promotes functional recovery and axonal regrowth in spinal cord-injured zebrafish. Pharmacol. Biochem. Behav. 2018, 171, 30-38. [CrossRef]

109. García-Fuster, M.J.; García-Sevilla, J.A. Effects of anti-depressant treatments on FADD and p-FADD protein in rat brain cortex: Enhanced anti-apoptotic p-FADD/FADD ratio after chronic desipramine and fluoxetine administration. Psychopharmacology 2016, 233, 2955-2971. [CrossRef]

110. Demougeot, C.; Garnier, P.; Mossiat, C.; Bertrand, N.; Giroud, M.; Beley, A.; Marie, C. N-Acetylaspartate, a marker of both cellular dysfunction and neuronal loss: Its relevance to studies of acute brain injury. J. Neurochem. 2001, 77, 408-415. [CrossRef]

111. Weinreb, O.; Amit, T.; Bar-Am, O.; Youdim, M.B.H. Ladostigil: A novel multimodal neuroprotective drug with cholinesterase and brain-selective monoamine oxidase inhibitory activities for Alzheimer's disease treatment. Curr. Drug Targets 2012, 13, $483-494$. [CrossRef]

112. Birks, J.; Flicker, L. Selegiline for Alzheimer's disease. Cochrane Database Syst. Rev. 2003, 1, CD000442. [CrossRef] [PubMed]

113. Zheng, H.; Amit, T.; Bar-Am, O.; Fridkin, M.; Youdim, M.B.; Mandel, S.A. From anti-Parkinson's drug rasagiline to novel multitarget iron chelators with acetylcholinesterase and monoamine oxidase inhibitory and neuroprotective properties for Alzheimer's disease. J. Alzheimers Dis. 2012, 30, 1-16. [CrossRef] [PubMed]

114. Gal, S.; Abassi, Z.A.; Youdim, M.B. Limited potentiation of blood pressure in response to oral tyramine by the anti-Parkinson brain selective multifunctional monoamine oxidase-AB inhibitor, M30. Neurotox. Res. 2010, 18, 143-150. [CrossRef]

115. Pletscher, A. The discovery of antidepressants: A winding path. Experientia 1991, 47, 4-8. [CrossRef] 
116. Gareri, P.; Falconi, U.; De Fazio, P.; De Sarro, G. Conventional and new antidepressant drugs in the elderly. Prog. Neurobiol. 2000, 61, 353-396. [CrossRef]

117. Makkar, R.; Behl, T.; Bungau, S.; Zengin, G.; Mehta, V.; Kumar, A.; Uddin, M.S.; Ashraf, G.M.; Abdel-Daim, M.M.; Arora, S.; et al. Nutraceuticals in neurological disorders. Int. J. Mol. Sci. 2020, 21, 4424. [CrossRef]

118. AlBasher, G.; Abdel-Daim, M.M.; Almeer, R.; Ibrahim, K.A.; Hamza, R.Z.; Bungau, S.; Aleya, L. Synergistic antioxidant effects of resveratrol and curcumin against fipronil-triggered oxidative damage in male albino rats. Environ. Sci. Pollut. Res. 2020, 27, 6505-6514. [CrossRef]

119. Parkinson Study Group. A randomized placebo-controlled trial of rasagiline in levodopa-treated patients with Parkinson disease and motor fluctuations: The PRESTO study. Arch. Neurol. 2005, 62, 241-248. [CrossRef]

120. Shoulson, I.; Fahn, S.; Oakes, D.; Lang, A.; Langston, J.W.; LeWitt, P.; Olanow, C.W.; Penney, J.B.; Tanner, C.; Kieburtz, K.; et al. Impact of deprenyl and tocopherol treatment on Parkinson's disease in DATATOP subjects not requiring levodopa. Ann. Neurol. 1996, 39, 29-36.

121. Rascol, O.; Brooks, D.J.; Melamed, E.; Oertel, W.; Poewe, W.; Stocchi, F.; Tolosa, E.; Group, L.S. Rasagiline as an adjunct to levodopa in patients with Parkinson's disease and motor fluctuations (LARGO, Lasting effect in Adjunct therapy with Rasagiline Given Once daily, study): A randomised, double-blind, parallel-group trial. Lancet 2005, 365, 947-954. [CrossRef]

122. Clarke, C.E. A “cure" for Parkinson's disease: Can neuroprotection be proven with current trial designs? Mov. Disord. 2004, 19, 491-498. [CrossRef] [PubMed]

123. Janssen, P.A.J.; Leysen, J.E.; Megens, A.A.H.P.; Awouters, F.H.L. Does phenylethylamine act as an endogenous amphetamine in some patients? Int. J. Neuropsychopharmacol. 1999, 2, 229-240. [CrossRef] [PubMed]

124. Li, X.-M.; Juorio, A.V.; Qi, J.; Boulton, A.A. L-Deprenyl induces aromatic l-amino acid decarboxylase (AADC) mRNA in the rat substantia nigra and ventral tegmentum. Mol. Chem. Neuropathol. 1998, 35, 149-155. [CrossRef] [PubMed]

125. Sieradzan, K.; Channon, S.; Ramponi, C.; Stern, G.M.; Lees, A.J.; Youdim, M.B.H. The therapeutic potential of moclobemide, a reversible selective monoamine oxidase A inhibitor in Parkinson's disease. J. Clin. Psychopharmacol. 1995, 15, 51S-59S. [CrossRef]

126. Weinstock, M.; Gorodetsky, E.; Poltyrev, T.; Gross, A.; Sagi, Y.; Youdim, M. A novel cholinesterase and brain-selective monoamine oxidase inhibitor for the treatment of dementia comorbid with depression and Parkinson's disease. Prog. Neuro Psychopharmacol. Biol. Psychiatry 2003, 27, 555-561. [CrossRef]

127. Poltyrev, T.; Gorodetsky, E.; Bejar, C.; Schorer-Apelbaum, D.; Weinstock, M. Effect of chronic treatment with ladostigil (TV-3326) on anxiogenic and depressive-like behaviour and on activity of the hypothalamic-pituitary-adrenal axis in male and female prenatally stressed rats. Psychopharmacology 2005, 181, 118-125. [CrossRef]

128. Waibel, S.; Reuter, A.; Malessa, S.; Blaugrund, E.; Ludolph, A.C. Rasagiline alone and in combination with riluzole prolongs survival in an ALS mouse model. J. Neurol. 2004, 251, 1080-1084. [CrossRef] 